\title{
Variability of Daily Maximum Wind Speed across China, 1975-2016: An Examination of Likely Causes ${ }^{\mathscr{O}}$
}

\author{
Gangfeng Zhang, ${ }^{\mathrm{a}, \mathrm{b}, \mathrm{c}}$ Cesar Azorin-Molina,,${ }^{\mathrm{c}, \mathrm{d}}$ Deliang Chen, ${ }^{\mathrm{c}}$ Jose A. Guijarro, ${ }^{\mathrm{e}}$ \\ Feng Kong, ${ }^{\mathrm{f}}$ Lorenzo Minola,${ }^{\mathrm{c}}$ Tim R. MCViCAR, ${ }^{\mathrm{g}, \mathrm{h}}$ SEOK-Woo Son, ${ }^{\mathrm{i}}$ AND PeiJun ShI ${ }^{\mathrm{a}, \mathrm{b}, \mathrm{j}}$ \\ ${ }^{a}$ State Key Laboratory of Earth Surface Processes and Resource Ecology, Beijing Normal University, Beijing, China \\ ${ }^{\mathrm{b}}$ Academy of Disaster Reduction and Emergency Management, Ministry of Emergency Management and Ministry of \\ Education, Beijing Normal University, Beijing, China \\ ${ }^{\mathrm{c}}$ Regional Climate Group, Department of Earth Sciences, University of Gothenburg, Gothenburg, Sweden \\ ${ }^{\mathrm{d}}$ Centro de Investigaciones sobre Desertificación, Consejo Superior de Investigaciones Científicas (CIDE-CSIC), \\ Valencia, Spain \\ ${ }^{\text {e }}$ State Meteorological Agency, Balearic Islands Office, Palma de Mallorca, Spain \\ ${ }^{\mathrm{f}}$ School of Public Policy and Management, Tsinghua University, Beijing, China \\ ${ }^{g}$ CSIRO Land and Water, Canberra, Australia \\ ${ }^{\mathrm{h}}$ Australian Research Council Centre of Excellence for Climate Extremes, Canberra, Australia \\ ${ }^{\text {i }}$ School of Earth and Environmental Sciences, Seoul National University, Seoul, South Korea \\ ${ }^{\mathrm{j}}$ Key Laboratory of Environmental Change and Natural Disaster of Ministry of Education, \\ Beijing Normal University, Beijing, China
}

(Manuscript received 10 August 2019, in final form 7 December 2019)

\begin{abstract}
Assessing change in daily maximum wind speed and its likely causes is crucial for many applications such as wind power generation and wind disaster risk governance. Multidecadal variability of observed near-surface daily maximum wind speed (DMWS) from 778 stations over China is analyzed for 1975-2016. A robust homogenization protocol using the R package Climatol was applied to the DMWS observations. The homogenized dataset displayed a significant $(p<0.05)$ declining trend of $-0.038 \mathrm{~m} \mathrm{~s}^{-1}$ decade $^{-1}$ for all China annually, with decreases in winter $\left(-0.355 \mathrm{~m} \mathrm{~s}^{-1}\right.$ decade $\left.^{-1}, p<0.05\right)$ and autumn $\left(-0.108 \mathrm{~m} \mathrm{~s}^{-1}\right.$ decade $\left.^{-1} ; p<0.05\right)$ and increases in summer $\left(+0.272 \mathrm{~m} \mathrm{~s}^{-1}\right.$ decade $\left.^{-1}, p<0.05\right)$ along with a weak recovery in spring $\left(+0.032 \mathrm{~m} \mathrm{~s}^{-1}\right.$ decade $^{-1} ; p>$ 0.10); that is, DMWS declined during the cold semester (October-March) and increased during the warm semester (April-September). Correlation analysis of the Arctic Oscillation, the Southern Oscillation, and the west Pacific modes exhibited significant correlation with DMWS variability, unveiling their complementarity in modulating DMWS. Further, we explored potential physical processes relating to the atmospheric circulation changes and their impacts on DMWS and found that 1) overall weakened horizontal airflow [large-scale mean horizontal pressure gradient (from -0.24 to $+0.02 \mathrm{hPa}$ decade $^{-1}$ ) and geostrophic wind speed (from -0.6 to $\left.+0.6 \mathrm{~m} \mathrm{~s}^{-1} \mathrm{decade}^{-1}\right)$ ],2) widely decreased atmospheric vertical momentum transport [atmospheric stratification thermal instability (from -3 to +1.5 decade $^{-1}$ ) and vertical wind shear (from -0.4 to $+0.2 \mathrm{~m} \mathrm{~s}^{-1} \mathrm{decade}^{-1}$ )], and 3 ) decreased extratropical cyclones frequency (from -0.3 to 0 month decade ${ }^{-1}$ ) are likely causes of DMWS change.
\end{abstract}

\section{Introduction}

Daily mean wind speed is widely used to investigate long-term trends of near-surface ( $\sim 10$-m height) wind speed (McVicar et al. 2012). Many recent studies have

Supplemental information related to this paper is available at the Journals Online website: https://doi.org/10.1175/JCLI-D-190603.s1.

Corresponding author: Peijun Shi, spj@bnu.edu.cn reported declining near-surface daily mean wind speed trends for the past decades over midlatitude continental surfaces (McVicar et al. 2008; Wan et al. 2010; AzorinMolina et al. 2014; Shi et al. 2015). Roderick et al. (2007) termed this declining trend stilling. Several drivers of stilling have been proposed, including 1) increased land surface roughness due to vegetation recovery (Vautard et al. 2010; Bichet et al. 2012) and urbanization (Wu et al. 2016; Z. Li et al. 2018); 2) decadal variability of atmospheric circulation (Azorin-Molina et al. 2014; Minola et al. 2016); and 3) instrumental issues such as 
TABLE 1. A review of long-term trends of DMWS studies over China using 10-m anemometer observations where $>10$ stations were used. The current study is added for completeness, and they are ordered chronologically by year then alphabetically.

\begin{tabular}{|c|c|c|c|c|c|c|c|}
\hline $\begin{array}{l}\text { Study } \\
\text { No. }\end{array}$ & Reference & $\begin{array}{l}\text { No. of } \\
\text { stations }\end{array}$ & Spatial extent & $\begin{array}{c}\text { Temporal } \\
\text { extent }\end{array}$ & Homogenized & $\begin{array}{c}\text { Trend } \\
\left(\mathrm{m} \mathrm{s}^{-1} \text { decade }^{-1}\right)\end{array}$ & Main finding(s) \\
\hline 1 & $\begin{array}{l}\text { Chen et al. } \\
\text { (2010) }\end{array}$ & 34 & $\begin{array}{l}\text { Jiangsu, } 9.77 \times 10^{4} \mathrm{~km}^{2} \\
\left(30^{\circ}-46^{\circ} \mathrm{N}, 116^{\circ}-122^{\circ} \mathrm{E},\right. \\
\text { south China })\end{array}$ & 1975-2008 & No & -0.821 & $\begin{array}{l}\text { Annual DMWS } \\
\text { significantly decreased } \\
\text { since the 1990s. }\end{array}$ \\
\hline 2 & $\begin{array}{l}\text { Jiang et al. } \\
\text { (2010) }\end{array}$ & 535 & All China, $960 \times 10^{4} \mathrm{~km}^{2}$ & 1956-2004 & No & -1.46 & $\begin{array}{l}\text { Overall decrease of } \\
\text { DMWS annually and in } \\
\text { all seasons. }\end{array}$ \\
\hline 3 & $\begin{array}{l}\text { Guo et al. } \\
\quad(2015)\end{array}$ & 35 & $\begin{array}{l}\text { Northeastern margin } \\
\text { of Qilian Mountains, } \\
4.2 \times 10^{4} \mathrm{~km}^{2}\left(36^{\circ}-40^{\circ} \mathrm{N},\right. \\
101^{\circ}-104^{\circ} \mathrm{E}, \\
\text { north China) }\end{array}$ & 1971-2013 & No & -1.11 & $\begin{array}{l}\text { Overall decrease of annual } \\
\text { DMWS in the whole } \\
\text { region, a break point was } \\
\text { detected in } 1988 \text { for } \\
\text { some stations. }\end{array}$ \\
\hline 4 & $\begin{array}{l}\text { Wang et al. } \\
\text { (2015) }\end{array}$ & 80 & $\begin{array}{l}\text { Anhui, } 13.86 \times 10^{4} \mathrm{~km}^{2} \\
\left(29^{\circ}-35^{\circ} \mathrm{N}, 114^{\circ}-120^{\circ} \mathrm{E},\right. \\
\text { central China })\end{array}$ & 1981-2012 & No & -0.5 to -2.5 & $\begin{array}{l}\text { Annual DMWS decreased } \\
\text { in the whole area. }\end{array}$ \\
\hline 5 & $\begin{array}{l}\text { Dong et al. } \\
\text { (2018) }\end{array}$ & 121 & $\begin{array}{l}\text { Shangdong, } 14.68 \times \\
10^{4} \mathrm{~km}^{2}\left(34^{\circ}-39^{\circ} \mathrm{N},\right. \\
\left.114^{\circ}-123^{\circ} \mathrm{E} \text {, east China }\right)\end{array}$ & 1981-2016 & No & -1.41 & $\begin{array}{l}\text { A break point (quicker } \\
\text { decreasing trend) of } \\
\text { annual DMWS was } \\
\text { detected around } 2002 .\end{array}$ \\
\hline 6 & $\begin{array}{l}\text { Current } \\
\text { study }\end{array}$ & 778 & All China, $960 \times 10^{4} \mathrm{~km}^{2}$ & 1975-2016 & Yes & -0.038 & $\begin{array}{l}\text { Overall decrease in annual } \\
\text { DMWS; however, a } \\
\text { distinct seasonal/ } \\
\text { monthly trend pattern } \\
\text { with significant declines } \\
\text { in winter-autumn and } \\
\text { increases in summer. }\end{array}$ \\
\hline
\end{tabular}

anemometer ageing (Azorin-Molina et al. 2018a). Contrary to this stilling phenomenon, positive near-surface daily mean wind speed trends have been reported over oceans (Wentz et al. 2007), for coastal areas (Pinard 2007), and in high-latitude regions (i.e., $>70^{\circ}$; $\mathrm{McVicar}$ et al. 2012; Minola et al. 2016). Moreover, after 3-5 decades of stilling, a stabilization or "recovery" of global average terrestrial winds commenced in 2013 (Tobin et al. 2014) and has continued in the last years (Dunn et al. 2016; Azorin-Molina et al. 2017, 2019; Zeng et al. 2019). Regional studies have also documented this recent recovery of land surface wind speeds (Kim and Paik 2015; Azorin-Molina et al. 2018b; Zhang et al. 2019).

Compared to the widely reported trends of terrestrial mean daily wind speed trends, the study of extreme wind speed changes [e.g., daily maximum wind speed (DMWS)], has only received minimal attention during the last two decades (Wu et al. 2018). Due to the skewed and possibly changing distribution of wind speed, there is no consensus regarding the trends in wind extremes relative to the mean, and the state of scientific knowledge regarding changes in extreme wind from anemometer observations on multidecadal time scales is currently inconclusive (Azorin-Molina et al. 2016; their Table 1). For instance, decreasing trends in wind speed extremes were reported in continental Europe [e.g., the Netherlands (Cusack 2013), Spain and Portugal (Azorin-Molina et al. 2016), and the Czech Republic (Brázdil et al. 2017)] and are broadly in agreement with stilling, whereas increasing wind speed extremes trends were documented in Japan (Fujii 2007), the United States (Klink 2015), and South Africa (Kruger et al. 2010). These findings point to more complicated features of extreme wind speed (e.g., DMWS) changes, which are both spatial and temporally nuanced, and calls for more careful interpretation and deeper understanding of its driving processes in more regions (e.g., China).

In China, all previous studies of long-term DMWS trends using anemometer observations did not employ quality control and homogenization methods to the raw DMWS series (Table 1). Further, only one study (Jiang et al. 2010) assessed annual DMWS changes using 535 stations across all China for 1954-2004, reporting a noticeable decline of $-1.46 \mathrm{~m} \mathrm{~s}^{-1}$ per decade. This means there are at least three opportunities for improvement when considering previous studies: 1) employing robust quality control and homogenization methods, which are important for resultant DMWS trend determination (Brázdil et al. 2017); 2) provision of an all-China DMWS multidecadal variability and trend assessment including 
recent records; and 3 ) use of more stations across China. Many atmospheric weather patterns drive DMWS over China (9.6 million $\mathrm{km}^{2}$ ), such as (i) typhoons along the southeastern coast (Wang et al. 2011), (ii) westerly winds in the north and in high-elevation mountains (Han et al. 2008), (iii) heavy thunderstorms (Yu et al. 2016), and (iv) the intensity of the summer and winter monsoons (Cui et al. 2019; Liu et al. 2018). Thus it is also important to investigate the physical processes driving DMWS variability and trends.

Wind electricity production is strongly influenced by integration of DMWS, as the wind power potential is a cube of the instant wind velocity (Karnauskas et al. 2018). The previously mentioned negative DMWS trend in continental Europe could lead to a loss of wind power potential, while using wind energy resources is rapidly becoming an integral part of many nations' strategies (e.g., China, Denmark, and Germany) toward realizing the carbon emissions reduction targets set forth in the Paris Agreement (Rogelj et al. 2016; Peters et al. 2017). Change of wind in recent decades has strongly affected wind erosion of soils in arid and semiarid areas over the world [e.g., southeast Spain (Segovia et al. 2017) and northern China (et al. 2019)], particularly as wind erosion only occurs when wind speed exceeds a threshold value (J. Zhang et al. 2017). Additionally, strong DMWS can damage building, infrastructure (Neumayer et al. 2014), and crops (Gardiner et al. 2016) and cause large economic losses; for example, strong DMWS disasters caused $\$ 4.13$ billion (U.S. dollars; converted from RMB based on the exchange rate in February 2019) losses over China in 2014 (Chinese Ministry of Civil Affairs, http://www.gov.cn/ xinwen/2015-01/05/content_2800233.htm; last accessed 1 November 2019).

The main objectives of this study are 1) to create a quality controlled and homogenized DMWS dataset for 1975-2016, 2) to detect multidecadal variability and trends at annual, seasonal, and monthly time scales, 3 ) to investigate the likely causes of the detected variabilities and changes by focusing on the role played by physical processes, especially atmospheric circulation patterns, in driving DMWS variations, and 4) to provide some new insights for management of the previously mentioned social and environment issues associated with DMWS, particularly in China.

\section{Data and methods}

\section{a. Anemometer observations}

Observed DMWS is the daily maximum 10-min mean surface (at 10-m height) wind speed from 2000 to 2000 UTC (the next day). The raw DMWS dataset was observed by the China Meteorological Administration (CMA; http://data.cma.cn/, last accessed 1 November 2019), and consisted of 2480 stations. Temporal evolution of DMWS data availability from January 1951 (44 stations) to December 2016 (2480 stations) is displayed in Fig. S1 in the online supplemental material. There is the abrupt increase of stations recording DMWS in the 1970s. For this reason, we commenced our analysis at the midyear of this decade (1975; i.e., 1109 stations). Further, stations with large amounts of missing data (i.e., $>5$ months in total since 1 January 1975) were excluded. Figure 1 shows the location of the resultant 778 stations for the 42-yr (i.e., 1975-2016) study period.

\section{b. Quality control and homogenization}

Station relocation, anemometer height and type changes (Wan et al. 2010), and anemometer aging (Azorin-Molina et al. 2018a) can produce artificial shifts in wind speed series. For example, CMA equipped the EL-type cup anemometers (Fig. S2) in most stations from 1975, while some stations have adopted EN-type cup anemometers (Fig. S2) since the early 1990s (Y. Li et al. 2018). As successfully applied previously (e.g., Azorin-Molina et al. 2016; Shi et al. 2019), the R package Climatol (Guijarro 2017; http://www.climatol.eu/; last accessed 1 November 2019) was used to perform quality control, relative homogenization, and missing data infilling on raw DMWS series. Climatol works with "normalized" values, and here normalizations were achieved by using the normal ratio method (dividing observed DMWS by the long-term averages of the DMWS series). Taking into account the large number of raw DMWS series over China, they were homogenized in 25 split areas that contain a more manageable number of stations. After an unsatisfactory first exploratory analysis without reanalysis, DMWS values from China were homogenized with maximum daily wind speeds calculated from the 6-hourly $U$ (zonal velocity in $\mathrm{ms}^{-1}$ ) and $V$ (meridional velocity in $\mathrm{ms}^{-1}$ ) wind from the National Centers for Environmental Prediction (NCEP)National Center for Atmospheric Research (NCAR) reanalysis data (see section $2 \mathrm{c}$ ) as complete references. This was performed to avoid abnormal termination of the homogenization in areas with low station density (i.e., northwest China and Tibet Plateau), yet was applied across all of China. However, in areas with higher station density of stations, it is expected that the influence of the reanalysis series will be much lower than that of observations. We adopted the same three-step homogenization approach developed by Azorin-Molina et al. (2018b). First, DMWS series (either present or missing) were estimated by averaging their 10 closest data at each time step, and differences between observed and calculated values were used for applying the well-established standard normal homogeneity test (SNHT; Alexandersson 1986) in two ways: 1) on 


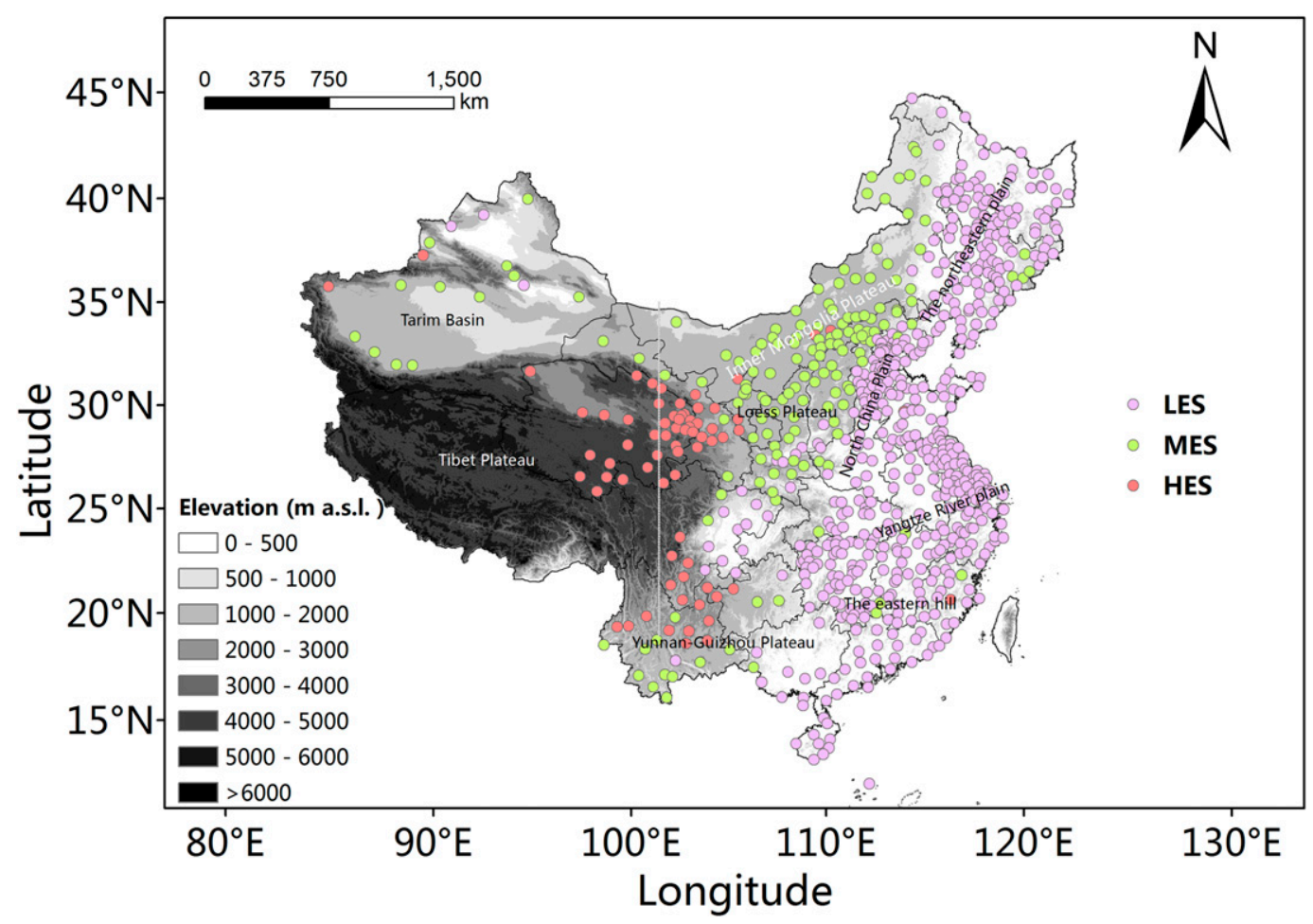

FIG. 1. Distribution of the 778 stations with homogenized DMWS data across China for 1975-2016. Stations are classified into three elevation categories: 1) low-elevation stations (LES; $<500 \mathrm{~m} \mathrm{MSL),} \mathrm{2)} \mathrm{mid-elevation} \mathrm{stations}$ (MES; 500-1500 m MSL), and 3) high-elevation stations (HES; >1500 m MSL).

stepped time windows to minimize the potential masking impacts of multiple breaks, and 2) on the whole series. Second, outliers exceeding a user-specified threshold were removed and their highest SNHT value was used to split the most inhomogeneous series. Thresholds were chosen with the help of the histograms of the anomalies and maximum SNHT values found in all series in exploratory homogenizations. In the absence of metadata, to avoid the rejection of actual extreme values, a high threshold was set at the cost of allowing more erroneous high values to be accepted. The quality control and homogenization process was repeated iteratively until no SNHT value higher than the user-specified threshold remained. Third, and last, all missing values were filled by means of averages of their four closest observations (weighted by an inverse distance function) creating a homogenized and complete DMWS series of 778 stations across China. The number of splits and an example of breakpoint detection can be found in Fig. 2.

\section{c. Reanalysis output}

To reveal the potential physical processes of atmospheric circulation affecting DMWS variability (see section 2e for details), reanalysis data for 6-hourly $U$ and $V$ wind at surface, monthly $U$ and $V$ wind at the surface and at 1000 and $850 \mathrm{hPa}$, geopotential height at $850 \mathrm{hPa}$, and atmospheric pressure at the surface and air temperature at 850, 700, and $500 \mathrm{hPa}$ obtained from the NCEP-NCAR dataset (https://www.esrl.noaa.gov/psd/data/gridded/data.ncep. reanalysis.pressure.html; last accessed 1 November 2019; $2.5^{\circ} \times 2.5^{\circ}$, Kalnay et al. 1996) from 1975 to 2016 were used. Additionally, to detect and track extratropical cyclones (ETCs), 6-h relative vorticity data at $850 \mathrm{hPa}$ from the European Centre for Medium-Range Weather Forecasts interim reanalysis (ERA-Interim; https://www.ecmwf.int/ en/forecasts/datasets/reanalysis-datasets/era-interim; last accessed 1 November 2019; $1^{\circ} \times 1^{\circ}$; Dee et al. 2011) for 1979-2016 was used. The higher-resolution ERA-Interim output, compared to NCEP-NCAR output, allows a better quantification of ETC properties (albeit for a shorter period). All reanalysis datasets were extracted for the area bounded by $15^{\circ}-55^{\circ} \mathrm{N}$ and $60^{\circ}-150^{\circ} \mathrm{E}$ (Fig. S3).

\section{d. Atmospheric circulation modes and indices}

Following previous studies where the relationships between daily mean wind speed variability and teleconnection indices were investigated in China (e.g., L. Chen et al. 2013; Y. Li et al. 2018), three atmospheric circulation modes were chosen to assess for the first time the influence of large-scale atmospheric circulation changes on observed DMWS variability. Our selection criteria include (i) the use of well-known and well-established 

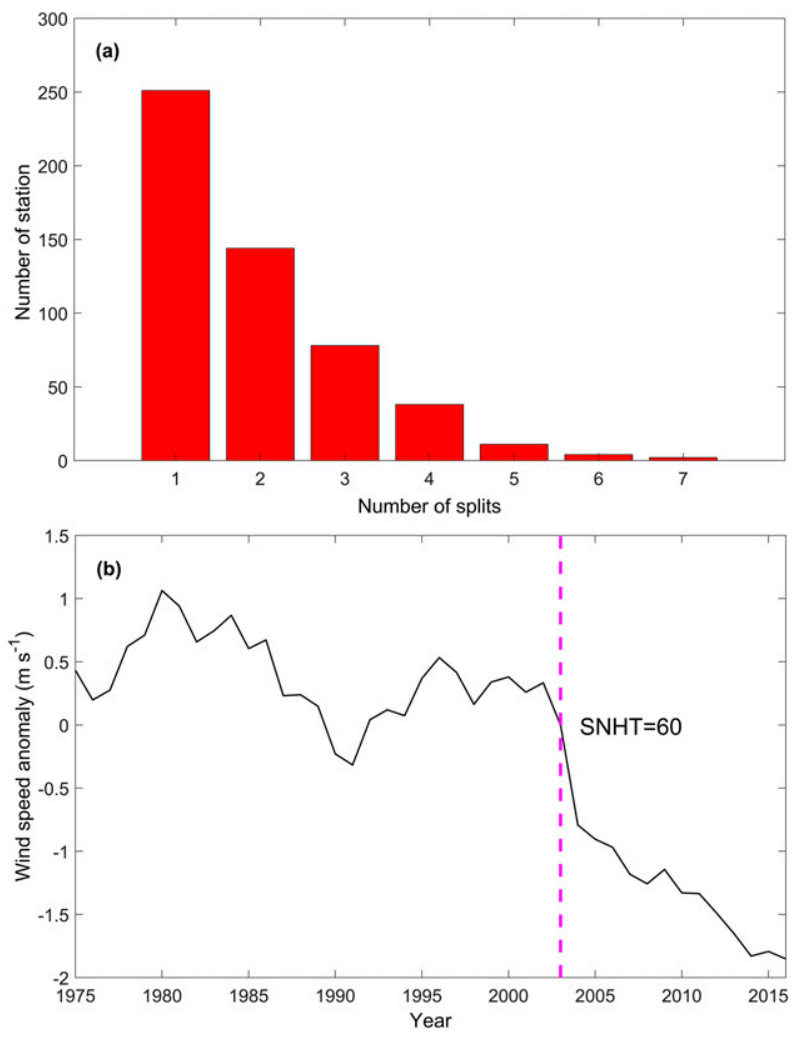

FIG. 2. (a) Histogram of the number of stations that suffered a various number of "splits" due to the detection of breakpoints. (b) Anomaly series $\left(\mathrm{m} \mathrm{s}^{-1}\right)$ of the Miyun station (mean DMWS $=$ $5.33 \mathrm{~m} \mathrm{~s}^{-1}$ ) illustrating the detection of the most significant breakpoint in 2003 (dashed line with the SNHT value $=60$ ).

indices and (ii) indices related to decadal variations of atmospheric circulation. These three modes are 1) the Arctic Oscillation index (AOI; Thompson and Wallace 1998), as constructed by projecting the $1000-\mathrm{hPa}$ height anomalies poleward of $20^{\circ} \mathrm{N}$ onto the loading pattern of the $\mathrm{AO}$, and loading pattern of the $\mathrm{AO}$ is defined as the leading mode of empirical orthogonal function (EOF) analysis of monthly mean 1000-hPa height during 1979-2000, obtained from the National Oceanic and Atmospheric Administration's Climate Prediction Center (NOAA CPC, http://www. cpc.ncep.noaa.gov/products/precip/CWlink/daily_ao_ index/ao_index.html, last accessed 1 November 2019); 2) the west Pacific index (WPI), which is a primary mode of low-frequency variability over the North Pacific in all months, downloaded from NOAA/NCEP (http://www.cpc.ncep.noaa.gov/data/teledoc/wp.shtml; last accessed 1 November 2019), as previously described by both Barnston and Livezey (1987) and Wallace and Gutzler (1981); and 3) the Southern Oscillation index (SOI) defined as the normalized pressure difference between Tahiti and Darwin as calculated by Ropelewski and Jones (1987) and retrieved from National Climate
Central of China (http://www.ncc-cma.net/cn/); last accessed 1 November 2019). As most of China is located in the monsoon region, the East Asian summer monsoon index (EASM; Li et al. 2010) and East Asian winter monsoon index (EAWM; Wang and He 2012) were also utilized.

The physical processes of atmospheric circulation affecting DMWS were first represented by the large-scale horizontal pressure gradient [Eq. (1)] between high latitudes (HL; i.e., $45^{\circ}-50^{\circ} \mathrm{N}$ ) and low latitudes (LL; i.e., $20^{\circ}-25^{\circ} \mathrm{N}$ ) for the longitudes between $70^{\circ}$ and $140^{\circ} \mathrm{E}$ (Fig. S3) and the regional horizontal pressure gradient force at $850 \mathrm{hPa}$ [Eq. (2)]. As wind speed over China was largely affected by the pressure gradient between the two bands according to the geostrophic approximation theory (Lin et al. 2013), and Y. Li et al. (2018) recently applied this to analyze contributions to wind speed changes under asymmetric warming, the large-scale horizontal pressure gradient provides enhanced understanding of the possible changes in the strength of horizontal airflow between HL and LL:

$$
\mathrm{PG}=\left(\sum_{i=1}^{n} \mathrm{PHL}_{i}-\sum_{i=1}^{n} \mathrm{PLL}_{i}\right) / n
$$

where PG refers to pressure gradient (hPa), $i$ indicates the grid number in each latitude, $n$ refers to the total number of grids in each latitude, and PHL and PLL indicate the gridcell near-surface air pressure in the HL and LL, respectively.

The regional horizontal pressure gradient force was represented by the geostrophic wind (Guo et al. 2011), which dominates horizontal airflow changes regionally, and calculated as

$$
V_{g}=-\frac{1}{f} \frac{\vartheta H}{\vartheta d}
$$

where $V_{g}$ refers to geostrophic wind $\left(\mathrm{m} \mathrm{s}^{-1}\right), f$ is the Coriolis parameter $\left(\mathrm{s}^{-1}\right), H$ is the geopotential height $\left(\mathrm{m}^{2} \mathrm{~s}^{-2}\right)$, and $\vartheta H$ is the pressure difference associated with the distance $\vartheta d(\mathrm{~m})$.

Further, vertical transport of atmospheric momentum changes was represented as vertical wind shear between 1000 and $850 \mathrm{hPa}$ (Shi et al. 2019) and atmospheric thermal stratification instability (index $A$, dimensionless; Zhang et al. 2014). Vertical wind shear [Eq. (3)] indicates the vertical air mixing in middle and lower troposphere, and directly affects the momentum downward dynamical transport from the middle and lower troposphere to the near surface, and is expressed as

$$
\mathrm{VWS}=\sqrt[2]{\left(U_{850}-U_{1000}\right)^{2}+\left(V_{850}-V_{1000}\right)^{2}},
$$


where VWS refers to vertical wind shear $\left(\mathrm{m} \mathrm{s}^{-1}\right)$, and $U$ and $V$ denote $U$ wind $\left(\mathrm{m} \mathrm{s}^{-1}\right)$ and $V$ wind $\left(\mathrm{m} \mathrm{s}^{-1}\right)$, respectively. The subscripts denote 850 and $1000 \mathrm{hPa}$.

An index $A$ indicating the strength of vertically thermal transport of the momentum at middle and lower troposphere can be derived:

$$
\begin{aligned}
A= & \left(T_{850}-T_{500}\right)-\left[\left(\mathrm{T}_{850}-\mathrm{Td}_{850}\right)\right. \\
& \left.+\left(T_{700}-\mathrm{Td}_{700}\right)+\left(T_{500}-\mathrm{Td}_{500}\right)\right],
\end{aligned}
$$

where $T$ and $\mathrm{Td}$ denote air temperature $\left({ }^{\circ} \mathrm{C}\right)$ and dewpoint temperature $\left({ }^{\circ} \mathrm{C}\right)$, respectively. The subscripts denote 500, 700, and $850 \mathrm{hPa}$.

Additionally, extratropical cyclones (ETCs) were also detected and tracked using 6-hourly 850-hPa relatively vorticity field as in Hoskins and Hodges (2002) and Cho et al. (2018), which represented the changed synoptic circulation change. Briefly, the relative vorticity was first filtered at a T42 spectral resolution and the local maximum was tracked by considering its direction and speed. The quasi-stationary thermal lows were then removed by considering sufficiently strong and migrating ETCs with a minimum intensity greater than $1.0 \times 10^{-5} \mathrm{~s}^{-1}$ [or 1 cyclonic vorticity unit (CVU)], a lifetime longer than two days, and a traveled distance greater than $1000 \mathrm{~km}$ (Hoskins and Hodges 2002). Tropical cyclones were also excluded by discarding cyclones that originated below $25^{\circ} \mathrm{N}$; see Hoskins and Hodges (2002) and Cho et al. (2018) for full details.

All ETC statistics were presented in a $1.5^{\circ}$ gridcell resolution as in ERA-Interim with area smoothing. The ETC frequency and intensity at a given grid cell represented those within a 555-km radius (Grise et al. 2013; Cho et al. 2018). For instance, one cyclone at a grid cell does not indicate one cyclone at the specific grid cell, but represents one cyclone within a $555-\mathrm{km}$ radius from the grid cell. This means that the same cyclone can be counted at multiple grid cells; see Grise et al. (2013) for details.

\section{e. Trend analyses and statistics}

DMWS anomalies were calculated as the deviation from the 1981-2010 DMWS mean for each station to avoid some high-wind speed series dominating the regional series if averaging stations regionally (AzorinMolina et al. 2014). Sen's slope method (Gilbert 1987) was used to calculate the magnitude of DMWS trends (in $\mathrm{m} \mathrm{s}^{-1}$ decade $^{-1}$ ), and an 11-yr Gaussian low-pass filter was computed to illustrate the DMWS multidecadal variability. We assessed the statistical significance of linear trends at annual, seasonal, and monthly time scales using the Mann-Kendall's tau-b nonparametric correlation coefficient (Kendall and Gibbons
1990). The statistical significance of DMWS trends was determined at three $p$-level thresholds (significant at $p<$ 0.05 , significant at $p<0.10$, and not significant at $p<$ 0.10) as proposed by McVicar et al. (2010), AzorinMolina et al. (2014, 2016), and Minola et al. (2016), among others. To determine if, and when, a change occurred (i.e., breakpoint year), we apply the effective and powerful changepoint analysis (Gavit et al. 2009). In addition, the Pearson product-moment correlation coefficient $(r)$ serves to measure the relationship between large-scale atmospheric circulation modes and DMWS variability. The relative contribution of each and all teleconnection indices for each region was estimated by multiple linear regression (Shi et al. 2019). Conventional definitions of the four boreal seasons were employed: winter [December-February (DJF)], spring [MarchMay (MAM)], summer [June-August (JJA)], and autumn [September-November (SON)].

We also assessed DMWS changes as a function of elevation. Previous research confirmed that local geographical settings can strongly influence the dynamics and trends of wind speed; for example, McVicar et al. (2010) documented that wind speed at high elevation is declining more quickly than at low elevations. Moreover, opposite wind speed trends were found below and above the trade-wind inversion layer in the Canary Islands (Azorin-Molina et al. 2018c). Considering China's complex topographic environment and that winds are sensitive to elevation change (Lin et al. 2013), following Y. Li et al. (2018) the homogenized data from the 778 stations were classified into three elevation groups (Fig. 1): (i) low-elevation stations [LES; $<500 \mathrm{~m}$ above mean sea level (MSL); 552 stations], (ii) mid-elevation stations (MES; 500-1500 m MSL; 155 stations), and (iii) high-elevation stations (HES; $>1500 \mathrm{~m}$ MSL; 71 stations). Moreover, DMWS variability was also investigated in seven subregions (Fig. S3) by using rotated empirical orthogonal function analysis and hierarchical clustering method (Guo et al. 2011; Lin et al. 2013). These are: northwest China (NWC; 18 stations), northeast China (NEC; 148 stations), north China (NC; 179 stations), northcentral China (NCC; 100 stations), south China (SC; 147 stations), east China (EC; 145 stations), and southwest China (SWC; 41 stations).

\section{Results}

\section{a. Climatology of DMWS over China}

Figure 3 shows the spatial variability of the homogenized mean, standard deviation, and maximum DMWS both annually and seasonally. Annually, two major features of mean DMWS are observed. First, DMWS displays a latitudinal gradient as northern stations 


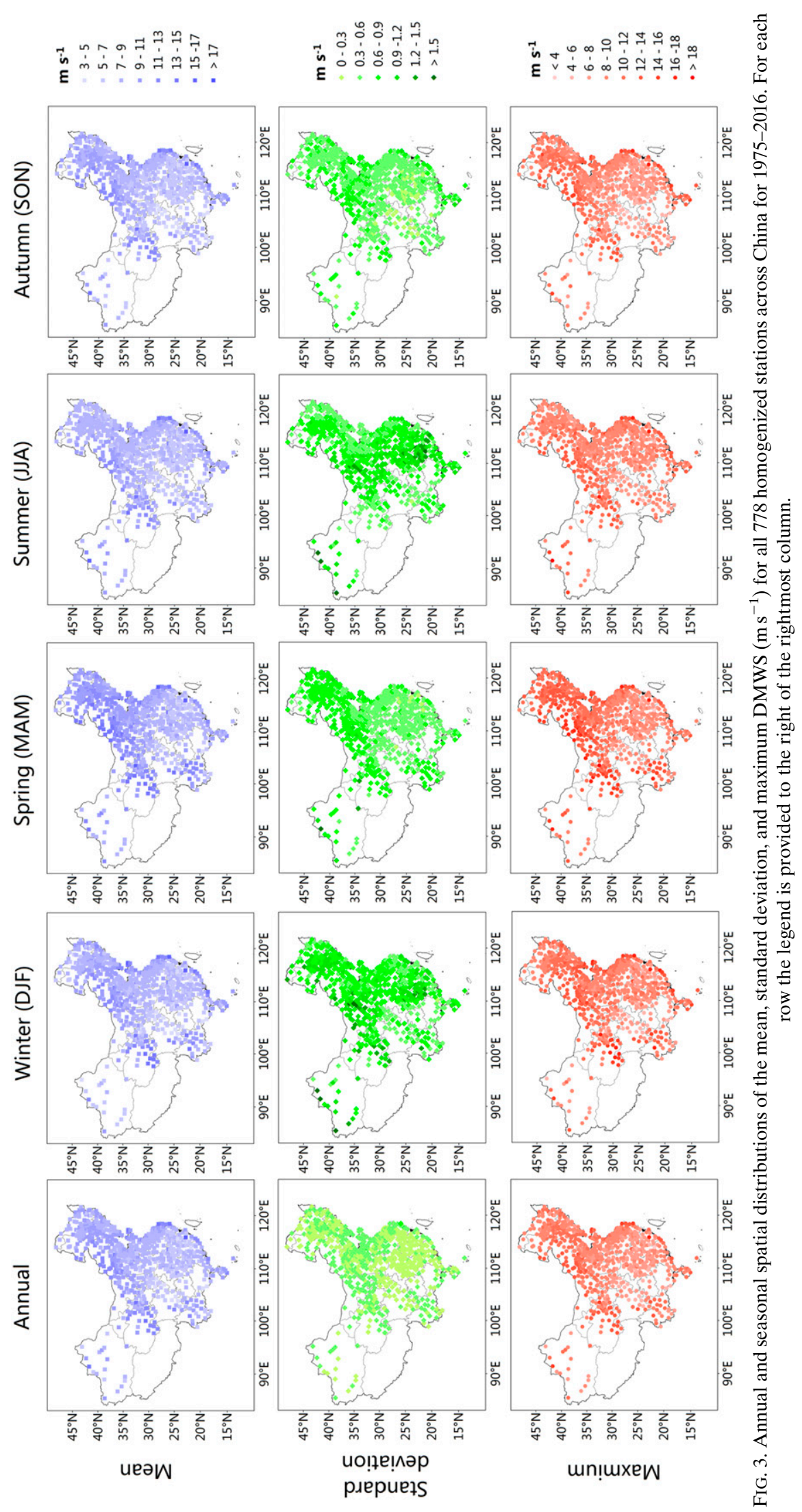


exhibited larger mean values than southern stations, with the exception of the high DMWS means observed in southern coastal areas, which is probably due to tropical cyclones and sea-land-breeze circulations (Jiang et al. 2013; Huang et al. 2016). Second, differences in DMWS means are also observed in relation to the elevation, with the highest annual mean DMWS in $\operatorname{HES}\left(9.9 \mathrm{~m} \mathrm{~s}^{-1}\right)$, followed by MES $\left(8.9 \mathrm{~m} \mathrm{~s}^{-1}\right)$ and LES $\left(8.1 \mathrm{~m} \mathrm{~s}^{-1}\right)$. Generally, elevation increases from southeast to northwest, which partly reinforces the latitudinal gradient. Seasonally, the latitudinal and elevation dependences of DMWS are also observed: spring is the windiest season $\left(9.4 \mathrm{~m} \mathrm{~s}^{-1}\right)$, followed by winter $\left(8.3 \mathrm{~m} \mathrm{~s}^{-1}\right)$, whereas for both summer $\left(8.0 \mathrm{~m} \mathrm{~s}^{-1}\right)$ and autumn $\left(8.0 \mathrm{~m} \mathrm{~s}^{-1}\right)$ DMWS tend to be much weaker. The same seasonal pattern is also detected for each of the elevation group series. Additionally, DMWS showed the highest standard deviations in winter and summer, likely due to the primary weather phenomena dominating each seasons, such as extratropical cyclones and Siberian/Mongolian high pressure systems in winter and typhoons/thunderstorms and local wind circulations in summer (Jiang et al. 2010; Wang et al. 2011). Maximum DMWS values are larger in spring and winter especially at HES (Fig. 3).

\section{b. Spatiotemporal distribution of DMWS trends}

Figure 4 shows the spatial distribution of the sign and magnitude of DMWS trends annually and seasonally, with the percentage of the stations showing negative and positive trends summarized in Table 2. Annually, DMWS declined at $71.5 \%$ of the stations, with $32.2 \%(p<0.05)$ and $42.8 \%(p<0.10)$ being significant. Many of the $28.5 \%$ of the sites with increased DMWS trends are located in northeast and southern coastal regions. Seasonally, a characteristic pattern emerges where decreasing DMWS trends dominating in winter and autumn, with marked decline in eastern and northern China (Fig. 4). In spring, there is near-equal percentage of stations showing negative and positive trends (Table 2). Stations where spring DMWS decreased are located in the northeast, northwest, and southern coastal areas, whereas stations where DMWS increased are found across southeast China (Fig. 4). Summer exhibits a distinct spatial pattern with many stations showing positive DMWS trend, with a marked large red area in eastern and northeastern China, while DMWS decreased mostly along the coastal areas (Fig. 4).

This characteristic seasonal spatial pattern is also clearly discernible in the monthly DMWS trend maps shown in Fig. S4 and their relative frequencies in Table 2. For example, the percentage of stations that exhibited negative trends exceeded $80 \%$ from October to February, reaching $96.3 \%$ in January, whereas from March to September a majority of stations exhibited positive DMWS trends, with the percentage of stations showing positive trends varying from $40.5 \%$ to about $87 \%$ in July (86.7\%) and August (87.1\%).

\section{c. Variability of DMWS at various time scales}

Table 3 summarizes the mean multidecadal DMWS trends and Fig. 5 displays the interannual variability of DMWS for all China and the three elevation classes. Annually, DMWS for all China decreased significantly $(p<0.05)$ at $-0.038 \mathrm{~m} \mathrm{~s}^{-1}$ decade $^{-1}$ over $1975-2016$. The magnitude of this declining trend increased with station elevation though: a stronger DMWS slowdown was determined for HES $\left(-0.067 \mathrm{~m} \mathrm{~s}^{-1}\right.$ decade $^{-1}, p<$ $0.05)$ when compared to LES $\left(-0.038 \mathrm{~m} \mathrm{~s}^{-1}\right.$ decade $^{-1}$, $p<0.05)$ and MES $\left(-0.029 \mathrm{~m} \mathrm{~s}^{-1}\right.$ decade $\left.^{-1}, p>0.10\right)$. Seasonally, the major finding is that negative DMWS trends for all China were detected in winter and autumn, while positive ones were observed in summer and spring albeit with a smaller magnitude and less statistical significance. For instance, winter experienced the strongest DMWS reduction of $-0.355 \mathrm{~m} \mathrm{~s}^{-1}$ decade $^{-1}(p<0.05)$ for the whole period. This significant slowdown was also detected for the three elevation classes. In autumn, DMWS trends for all China reduced at a lesser rate, yet were still significant $\left(-0.108 \mathrm{~m} \mathrm{~s}^{-1}\right.$ decade $\left.^{-1}, p<0.05\right)$, with similar results for LES, MES, and HES. In contrast, DMWS for all China increased in summer $\left(+0.272 \mathrm{~m} \mathrm{~s}^{-1}\right.$ decade $^{-1}, p<$ 0.05 ), with a marked increase since 2000 , and significant changepoints were detected in $1994(p<0.05)$ and 2003 $(p<0.05)$. When analyzing the DMWS trends in summer for the three elevation classes, significant $(p<0.05)$ increases were detected for LES $\left(+0.304 \mathrm{~m} \mathrm{~s}^{-1}\right.$ decade $\left.^{-1}\right)$ and MES $\left(+0.269 \mathrm{~m} \mathrm{~s}^{-1}\right.$ decade $\left.^{-1}\right)$, while they were nonsignificant $(p>0.10)$ for HES $\left(+0.043 \mathrm{~m} \mathrm{~s}^{-1}\right.$ decade $\left.^{-1}\right)$. Last, spring DMWS trends for all China were negligible $\left(+0.032 \mathrm{~m} \mathrm{~s}^{-1}\right.$ decade $\left.^{-1}, p>0.10\right)$, with a significant changepoint detected in $2004(p<0.05)$, and positive for all elevation strata series but nonsignificant $(p>0.10)$. Moreover, a clear intra-annual cycle of DMWS trends was detected, which significantly $(p<0.05)$ increased from May to September and was nonsignificant $(p>0.10)$ in April before it significantly $(p<0.05)$ decreased from October to February with a nonsignificant $(p>0.10)$ decrease in March transition. The same intra-annual trend cycle patterns were found for all three elevation-stratified series (Table 3 and Fig. 5).

Further, considering the great spatial variability in Fig. 4, DMWS trends and variability in seven subregions are also investigated (Table 3, Fig. 6). Annually, all regions showed declining DMWS trends for the whole period except NWC, where a nonsignificant recovery of 

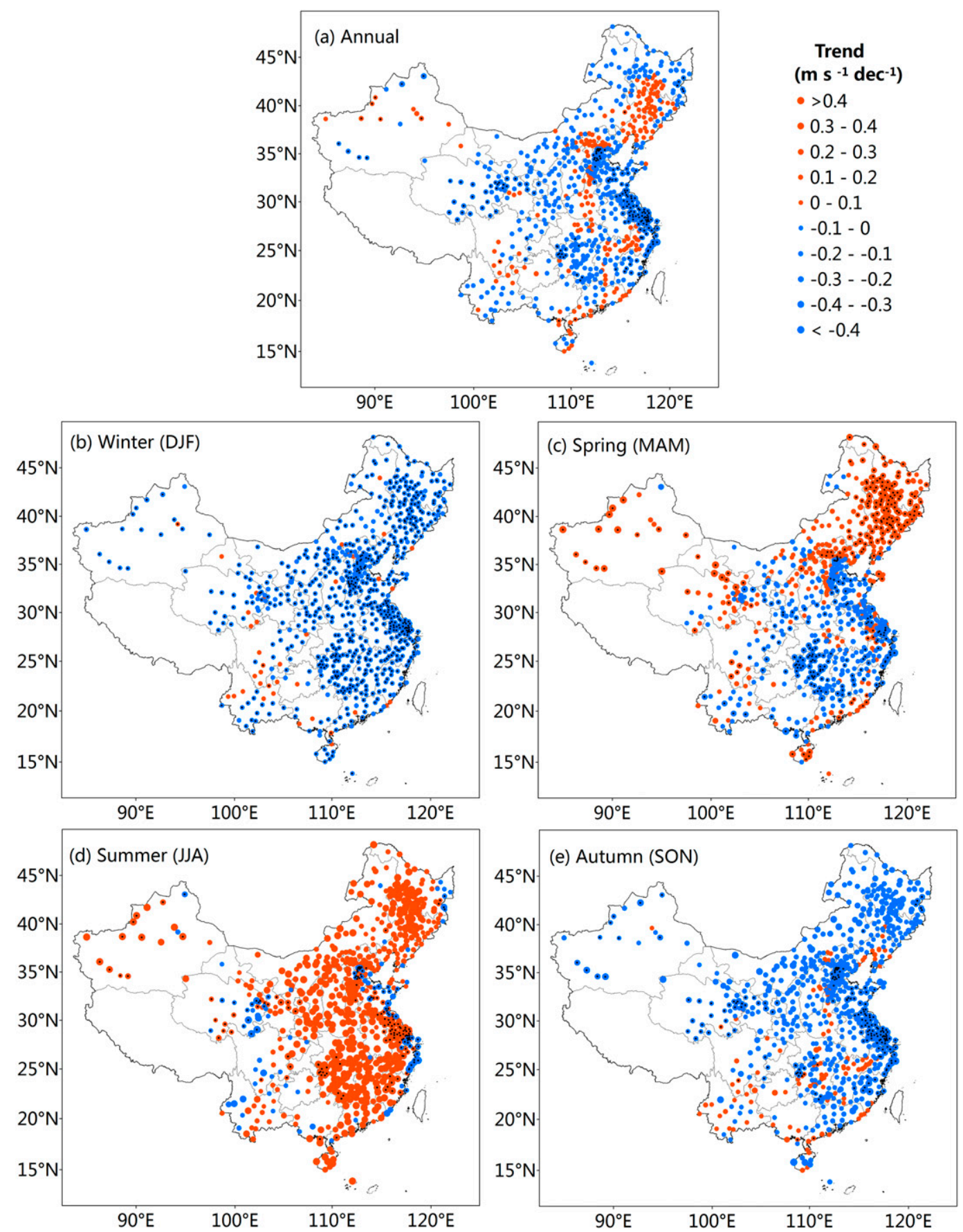

FIG. 4. Spatial distribution of annual and seasonal sign and magnitude of trends as well as associated significance in DMWS across China for 1975-2016. A small black dot in a circle indicates a significant trend at $p<0.05$.

DMWS $\left(+0.001 \mathrm{~m} \mathrm{~s}^{-1} \mathrm{decade}^{-1}, p>0.10\right)$ was detected. Seasonally, significant $(p<0.05)$ negative trends of DMWS dominated all regions in winter, with the highest magnitude $\left(-0.630 \mathrm{~m} \mathrm{~s}\right.$ decade $\left.^{-1}\right)$ in NWC. Spring experienced significant $(p<0.05)$ increasing DMWS trends in NEC and NWC, while decreasing DMWS trends were found in the rest of subregions. Similar to elevation categories, all the regions exhibited significant $(p<0.10)$ positive trends of DMWS in summer, particularly in SC $\left(+0.533 \mathrm{~m} \mathrm{~s}^{-1}\right.$ decade $\left.^{-1}\right)$ and NWC $\left(+0.467 \mathrm{~m} \mathrm{~s}^{-1}\right.$ decade $\left.^{-1}\right)$.While autumn showed decreasing DMWS trends in all subregions, except a nonsignificant slight recovery $\left(+0.015 \mathrm{~m} \mathrm{~s}^{-1}\right.$ decade $\left.^{-1} ; p<0.10\right)$ of DMWS in SWC. Besides, the same intra-annual trend 
TABLE 2. Relative frequency (\%) of the 778 CMA stations that exhibited positive and negative trends of DMWS for various significance tests at annual, seasonal, and monthly time scales for all China, 1975-2016.

\begin{tabular}{|c|c|c|c|c|c|c|c|c|}
\hline & Negative & $\begin{array}{l}\text { Negative } \\
\text { significant } \\
p<0.05\end{array}$ & $\begin{array}{c}\text { Negative } \\
\text { significant } \\
p<0.10\end{array}$ & $\begin{array}{c}\text { Negative } \\
\text { nonsignificant } \\
p>0.10\end{array}$ & Positive & $\begin{array}{c}\text { Positive } \\
\text { significant } \\
p<0.05\end{array}$ & $\begin{array}{c}\text { Positive } \\
\text { significant } \\
p<0.10\end{array}$ & $\begin{array}{c}\text { Positive } \\
\text { nonsignificant } \\
p>0.10\end{array}$ \\
\hline Annual & 71.5 & 32.2 & 42.8 & 57.2 & 28.5 & 4.1 & 9.0 & 91.0 \\
\hline Winter & 94.9 & 87.3 & 90.7 & 9.3 & 5.1 & 10.0 & 17.5 & 82.5 \\
\hline Spring & 52.2 & 36.7 & 46.1 & 53.9 & 47.8 & 49.5 & 56.7 & 43.3 \\
\hline Summer & 14.0 & 30.3 & 36.7 & 63.3 & 86.0 & 75.9 & 81.6 & 18.4 \\
\hline Autumn & 85.0 & 54.3 & 62.2 & 37.8 & 15.0 & 8.5 & 12.8 & 87.2 \\
\hline January & 96.3 & 87.7 & 90.5 & 9.5 & 3.7 & 13.8 & 17.2 & 82.8 \\
\hline February & 90.9 & 69.6 & 77.1 & 22.9 & 9.1 & 9.9 & 15.5 & 84.5 \\
\hline March & 59.5 & 57.2 & 63.5 & 36.5 & 40.5 & 21.6 & 33.3 & 66.7 \\
\hline April & 54.4 & 25.5 & 38.1 & 61.9 & 45.6 & 43.1 & 49.6 & 50.4 \\
\hline May & 23.5 & 16.4 & 22.4 & 77.6 & 76.3 & 37.0 & 47.1 & 52.9 \\
\hline June & 21.3 & 36.1 & 44.0 & 56.0 & 78.7 & 64.5 & 71.6 & 28.4 \\
\hline July & 13.9 & 25.9 & 31.5 & 68.5 & 86.1 & 69.3 & 75.1 & 24.9 \\
\hline August & 12.9 & 20.0 & 26.0 & 74.0 & 87.1 & 67.7 & 75.7 & 24.3 \\
\hline September & 37.3 & 25.5 & 37.6 & 62.4 & 62.7 & 51.0 & 57.8 & 42.2 \\
\hline October & 85.9 & 39.2 & 51.8 & 48.2 & 14.1 & 10.0 & 20.0 & 80.0 \\
\hline November & 92.3 & 70.2 & 77.9 & 22.1 & 7.7 & 16.7 & 23.3 & 76.7 \\
\hline December & 93.2 & 74.5 & 80.0 & 20.0 & 6.8 & 11.3 & 17.0 & 83.0 \\
\hline
\end{tabular}

cycle patterns were found for all subregions stratified series (see Table 3 and Fig. 6).

\section{d. Relationship with large-scale atmospheric circulation modes}

Figure 7 shows the spatial distribution of the stationbased $r$ coefficient between observed DMWS anomalies and the three atmospheric circulation indices, AOI, WPI, and SOI, both annually and seasonally. Table 4 reports the most significantly correlated atmospheric teleconnection indices for each of the four (i.e., all China, LES, MES, and HES) series for 1975-2016.
Overall, the atmospheric circulation series show significant $(p<0.05)$ correlations with the DMWS variability, indicating the important role these three indices had in shaping DMWS variability across China. As shown in Fig. 7 and Table 4, AO exhibited the most significant negative relationship with the DMWS annually and in spring and winter, SO exerted its major significant negative influence in winter, and WP showed most significant negative impact in summer and had significant positive impacts on the annual mean. The mechanisms that explain how atmospheric circulation modes affect DMWS are found in section 4.

TABLE 3. DMWS trends $\left(\mathrm{m} \mathrm{s}^{-1}\right.$ decade $\left.^{-1}\right)$ for all China, LES, MES, and HES at annual, seasonal, and monthly time scales for 1975-2016. Statistically significant values at $p<0.10$ are in parentheses and $p$ values $<0.05$ are bolded.

\begin{tabular}{|c|c|c|c|c|c|c|c|c|c|c|c|}
\hline \multirow[b]{2}{*}{ Periods } & \multirow[b]{2}{*}{ All } & \multicolumn{3}{|c|}{ Elevation categories } & \multicolumn{7}{|c|}{ Subregions } \\
\hline & & LES & MES & HES & NWC & NEC & $\mathrm{NC}$ & $\mathrm{NCC}$ & $\mathrm{SC}$ & $\mathrm{EC}$ & SWC \\
\hline Annual & -0.038 & -0.038 & -0.029 & -0.067 & 0.001 & -0.015 & -0.041 & -0.080 & -0.015 & -0.091 & -0.008 \\
\hline Winter & -0.355 & -0.380 & -0.324 & -0.214 & -0.630 & -0.441 & -0.304 & -0.321 & -0.462 & -0.394 & -0.124 \\
\hline Spring & 0.032 & 0.028 & 0.047 & 0.053 & 0.346 & 0.247 & -0.004 & -0.003 & -0.074 & -0.058 & -0.022 \\
\hline Summer & 0.272 & 0.304 & 0.269 & 0.043 & 0.467 & 0.250 & 0.195 & 0.185 & 0.533 & 0.212 & $(0.085)$ \\
\hline Autumn & -0.108 & -0.116 & $-\mathbf{0 . 1 1 7}$ & -0.095 & -0.197 & -0.147 & $(-0.120)$ & $-\mathbf{0 . 1 3 3}$ & -0.060 & -0.140 & 0.015 \\
\hline January & -0.493 & -0.516 & -0.468 & -0.310 & -0.762 & -0.645 & -0.457 & -0.417 & -0.060 & -0.481 & -0.148 \\
\hline February & -0.285 & -0.306 & -0.271 & -0.047 & -0.469 & $(-0.149)$ & -0.296 & -0.221 & -0.431 & -0.331 & -0.096 \\
\hline March & -0.068 & -0.069 & -0.033 & -0.048 & 0.038 & 0.162 & 0.001 & -0.132 & -0.329 & $(-0.136)$ & -0.239 \\
\hline April & 0.027 & 0.016 & 0.028 & 0.099 & 0.386 & 0.268 & -0.032 & 0.032 & $(-0.123)$ & -0.045 & 0.023 \\
\hline May & 0.132 & 0.123 & (0.192) & 0.114 & 0.582 & 0.282 & 0.074 & 0.090 & 0.152 & 0.021 & 0.154 \\
\hline June & 0.208 & 0.218 & 0.263 & 0.069 & 0.719 & 0.315 & 0.100 & 0.192 & 0.353 & 0.033 & 0.058 \\
\hline July & 0.289 & 0.327 & 0.291 & 0.013 & 0.531 & 0.206 & 0.225 & 0.209 & 0.615 & 0.266 & 0.020 \\
\hline August & 0.317 & 0.357 & 0.310 & 0.019 & 0.142 & 0.213 & 0.263 & 0.154 & 0.666 & 0.280 & 0.158 \\
\hline September & $(0.070)$ & 0.094 & 0.015 & -0.006 & $(0.070)$ & -0.068 & -0.006 & 0.041 & 0.327 & 0.078 & 0.070 \\
\hline October & -0.110 & -0.128 & -0.076 & -0.075 & -0.199 & -0.173 & -0.122 & -0.120 & -0.112 & -0.159 & 0.001 \\
\hline November & -0.301 & -0.313 & -0.325 & -0.207 & -0.465 & -0.190 & -0.257 & -0.321 & -0.417 & -0.373 & -0.015 \\
\hline December & -0.357 & -0.351 & -0.329 & -0.396 & -0.620 & -0.362 & $(-0.224)$ & -0.458 & -0.454 & -0.363 & -0.155 \\
\hline
\end{tabular}



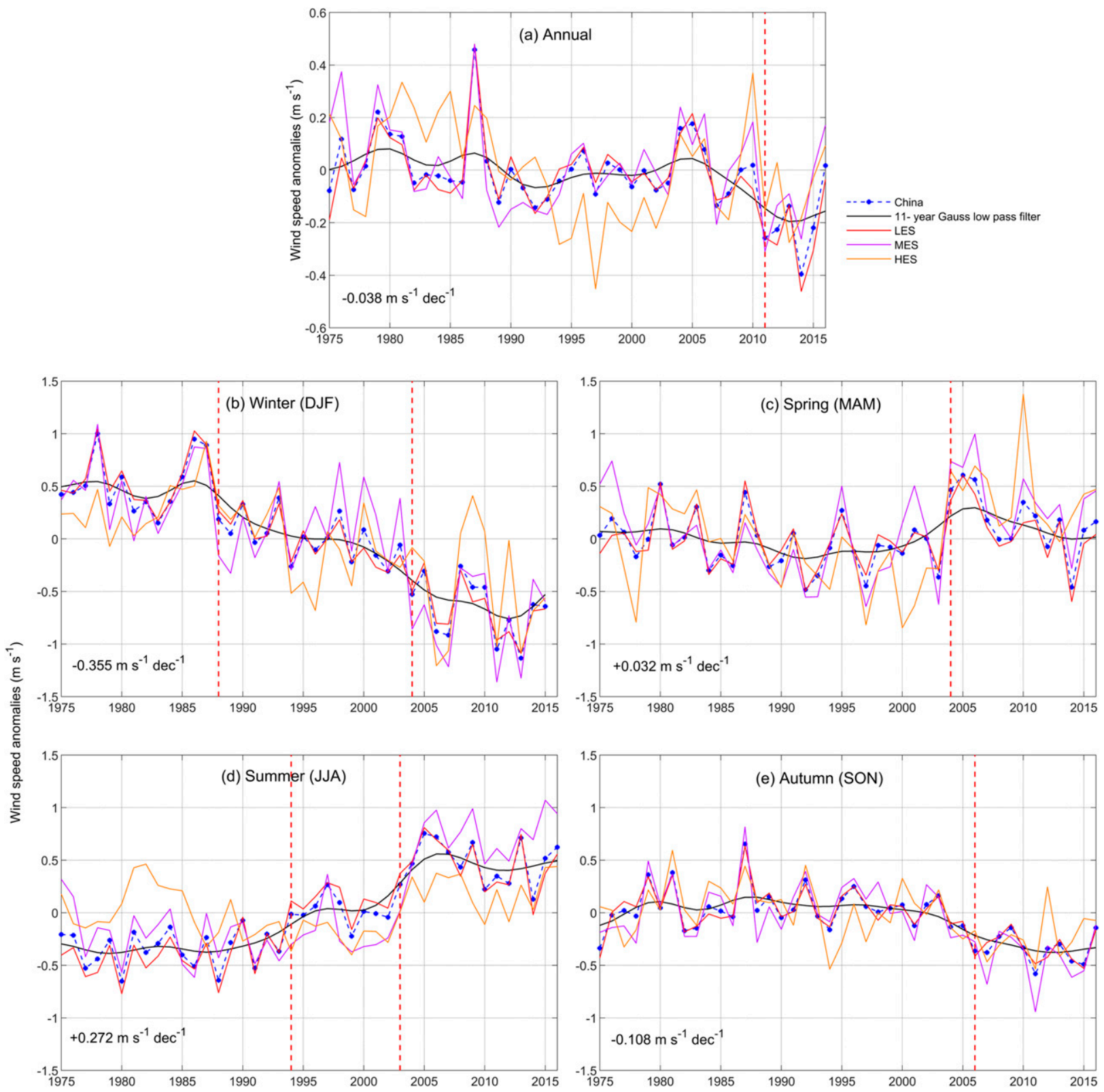

FIG. 5. Mean (a) annual and (b)-(e) seasonal DMWS anomalies ( $\mathrm{m} \mathrm{s}^{-1}$ ) over all China and for the LES, MES, and HES series from 1975 to 2016. The 11-yr Gaussian low-pass filter (provided by the black solid line) highlights the all-China multidecadal variability, trend (number; $\mathrm{m} \mathrm{s}^{-1}$ decade $^{-1}$ ) and most significant changepoints (red dashed lines; $p<0.05$ ) displayed in each subplot only for all China. The legend for (a) applies to all panels.

Table 4 shows that annually AOI exerted the most significant and strongest impacts on DMWS $(r=-0.47$, $p<0.05)$ compared to the other atmospheric indices. The negative relationship between AOI and DMWS was found for all China, as shown by the significant $(p<0.05)$ $r$ value for all four series. Spatially, most stations show a negative relationship (Table 5), with most of the stations having significant $(p<0.05)$ relationships located in the North China Plain (Fig. 7; see Fig. 1 for the location of the
North China Plain). Therefore, decreased annual DMWS trends might have been associated with the enhanced AO $(+0.05, p<0.10)$ over the past four decades. Note that WP also displayed a significant $(r=+0.46, p<0.05)$ and positive relationship with DMWS trends, being most significant $(p<0.05)$ in eastern and northeastern China (Fig. 7). The WPI showed a negative tendency $\left(-0.09\right.$ decade $\left.^{-1}, p<0.10\right)$ for 1975-2016 (Table 5), particularly in the last decade. This might partly explain 

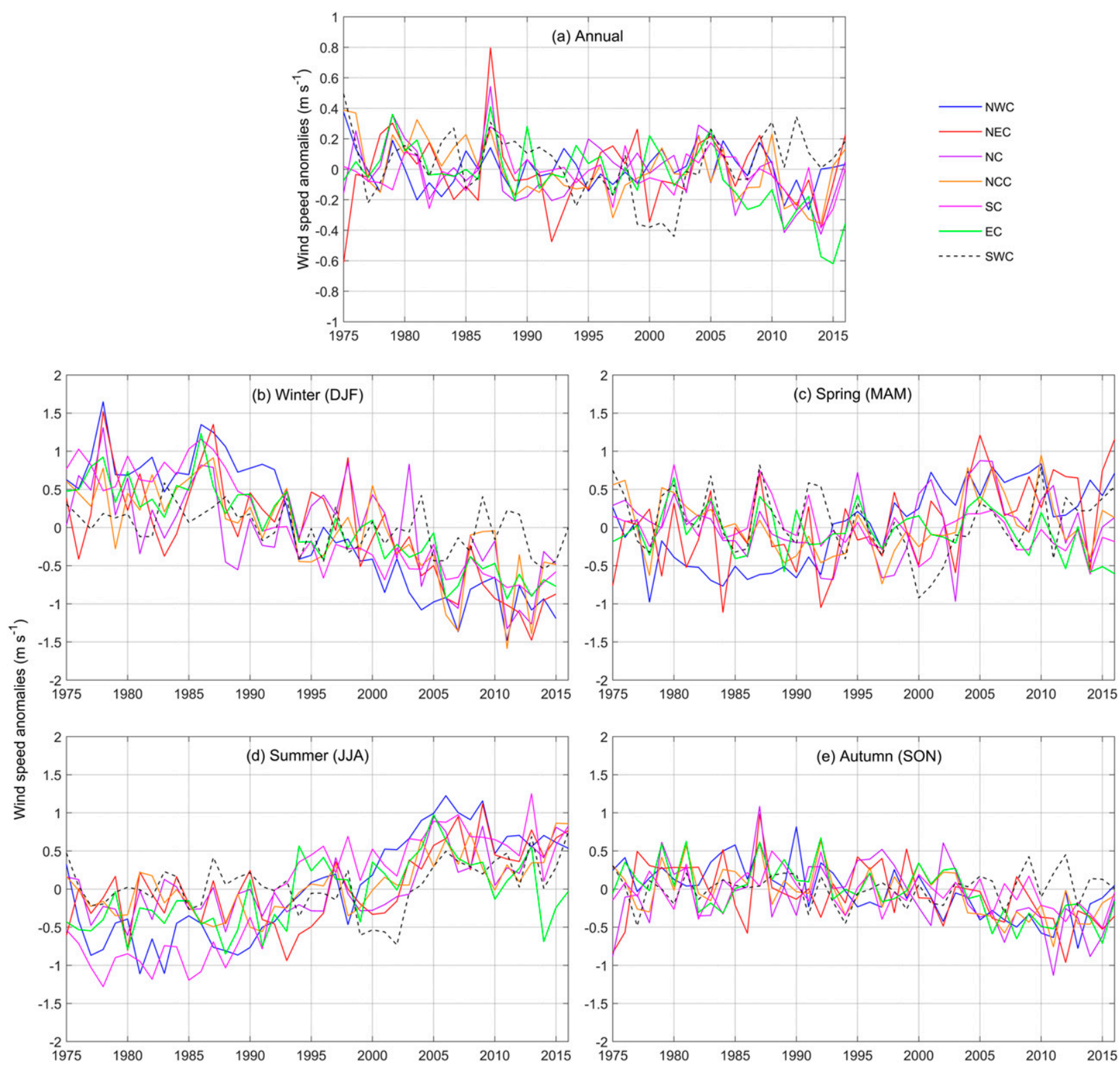

FIG. 6. As in Fig. 5, but for seven subregions of China.

the annual decline in DMWS observed across China. The weak negative relation $(-0.13, p>0.10)$ between SOI and annual DMWS was detected, and stations with significant $(p<0.05)$ negative correlation were mostly located in the North China Plain.

Seasonally (Table 5 and Fig. 7), significant negative relationships of AO with DMWS are found in spring ( $r$ value $-0.37, p<0.05)$ and autumn $(-0.34, p<0.05)$; many of the stations that exhibited a significant $(p<$ 0.05) negative relationship located on the North China Plain in autumn and eastern China in spring. When assessing the long-term trends of spring and autumn AO, a weak increase of spring AO (+0.09 decade $\left.^{-1}, p>0.10\right)$ and decrease of autumn $\mathrm{AO}\left(-0.02\right.$ decade $\left.^{-1}, p>0.10\right)$ are found (Table 5). For summer, WP affects the DMWS trends, yielding a significant negative relationship $(-0.38, p<0.05)$; many stations that reported this significant negative relationship were located in southern China. It is worth mentioning that the negative relationship is stronger in LES $(-0.38$, $p<0.05)$, and MES $(-0.32, p<0.05)$, compared to HES $(-0.23, p>0.1)$. The summer WP became more negative $\left(-0.35\right.$ decade $\left.^{-1}, p<0.05\right)$ for $1975-2016$, suggesting that more negative phases contributed to the increased summer DMWS trends, particularly at LES and MES. Last, SO showed the strongest 


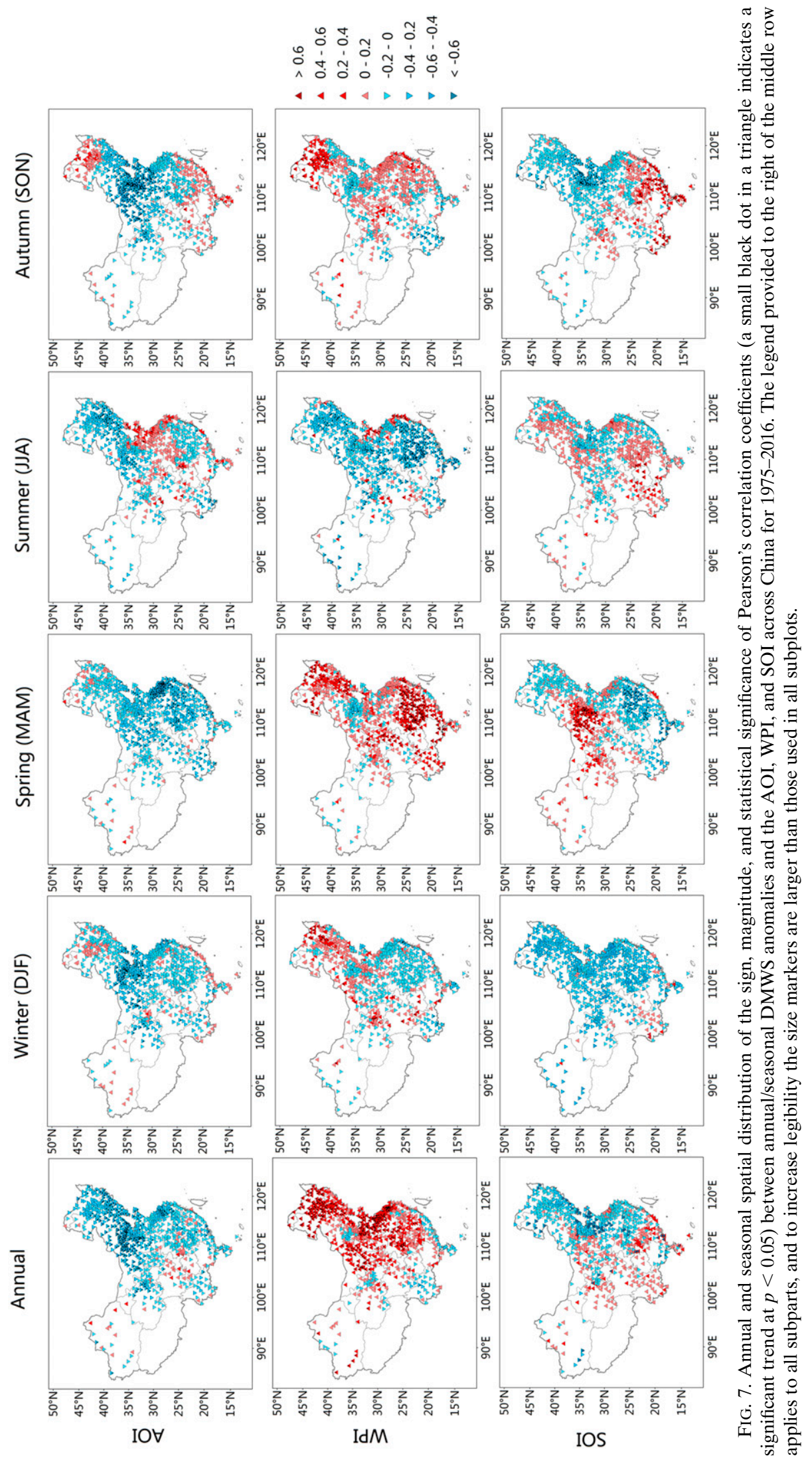


TABLE 4. Most significant correlated atmospheric circulation indices with annual and seasonal DMWS series for all China, LES, MES, and HES for 1975-2016. Statistically significant correlations defined as those with $p<0.10$ are in parentheses and $p<0.05$ are bolded. AO denotes Arctic Oscillation, SO Southern Oscillation, and WP the west Pacific teleconnection pattern (defined in section 2d).

\begin{tabular}{|c|c|c|c|c|}
\hline Time scale & China & LES & MES & HES \\
\hline Annual & $\mathrm{AO}-\mathbf{0 . 4 7}$ & $\mathrm{AO}-\mathbf{0 . 4 7}$ & AO $\mathbf{- 0 . 5 3}$ & $\mathrm{AO}-\mathbf{0 . 3 2}$ \\
\hline Winter (DJF) & $\mathrm{SO}-\mathbf{0 . 3 4}$ & SO -0.35 & SO $(-0.29)$ & $\mathrm{AO}-\mathbf{- 0 . 3 4}$ \\
\hline Spring (MAM) & $\mathrm{AO}-\mathbf{0 . 3 7}$ & $\mathrm{AO}-\mathbf{0 . 3 7}$ & $\mathrm{AO}(-0.27)$ & $\mathrm{AO}-0.23$ \\
\hline Summer (JJA) & WP -0.38 & WP -0.38 & WP -0.32 & $\mathrm{WP}-0.23$ \\
\hline Autumn (SON) & $\mathrm{AO}-\mathbf{0 . 3 4}$ & $\mathrm{AO}-0.25$ & $\mathrm{AO}-\mathbf{0 . 4 7}$ & $\mathrm{AO}-\mathbf{0 . 3 4}$ \\
\hline
\end{tabular}

negative correlation $(-0.34, p<0.05)$ with DMWS in winter, when $>90 \%$ of stations (Table 5) displayed a negative relationship, particularly in the North China Plain (Fig. 7). This impact of SO on DMWS is also strongest for LES $(-0.35, p<0.05)$ and MES $(-0.29$, $p<0.05)$, while the AO has the strongest impacts on HES $(-0.34, p<0.05$; see Table 4$)$.

\section{e. Potential physical processes associated with atmospheric circulation change}

Figure 8 displays the variability of horizontal pressure gradient between the high-latitude and low-latitude zones annually and seasonally. Annually, the pressure gradient significantly $(p<0.05)$ declined by $-0.16 \mathrm{hPa}$ decade $^{-1}$, and the 11-yr Gaussian low-pass filter generally decreased for the whole 1975-2016 period. Seasonally, winter and autumn showed significant $(p<0.10)$ declining trends of pressure gradient for the whole study period, at -0.26 and $-0.14 \mathrm{hPa}$ decade $^{-1}$, respectively. Most interestingly, for summer, the pressure gradient significantly decreased $\left(-0.24 \mathrm{hPa}\right.$ decade $\left.^{-1}, p<0.10\right)$ until 2001 , when it suddenly increased at $+0.90 \mathrm{hPa}$ decade $^{-1}(p>0.10)$ between 2002 and 2013 (no significant changepoint was detected).
Last, spring displayed a nonsignificant $(p>0.10)$ weak increase trend of pressure gradient $\left(+0.02 \mathrm{hPa}\right.$ decade $\left.^{-1}\right)$, with a decrease of the pressure gradient from 1975 to 1989 and a significant recovery since 1990 (Fig. 8).

Figure 9 shows the trends of geostrophic wind speed for China and surrounding areas, and shows that annually, weakening geostrophic wind speeds (from -0.3 to $0 \mathrm{~m} \mathrm{~s}^{-1}$ decade $^{-1}$ ) were found from northeast to east China, which is consistent with the widespread DMWS decreases reported previously (see Fig. 4 and Table 3) in north and east China. Meanwhile, opposite enhanced geostrophic wind speeds $\left(0-0.3 \mathrm{~m} \mathrm{~s}^{-1}\right.$ decade $\left.^{-1}\right)$ were shown in northwest to southwest China; this pattern partly explained the increasing DMWS there. Seasonally, winter experienced a widely decreased geostrophic wind speed in the whole country, except parts of northwest and southwest China, corresponding to the spatial pattern of DMWS trends (Fig. 4b). For spring, geostrophic wind speeds moderately decreased in east China and the recovery of geostrophic wind speeds in part of northeast China concur with the DMWS trends (Fig. 4c). The strongest declining geostrophic wind speed occurred in northwest China, where DMWS increased (Fig. 4c).

TABLE 5. Annual and seasonal trends $\left(\mathrm{decade}^{-1}\right)$ of AOI, WPI, and SOI for 1975-2016 and relative frequency (\%) of positive and negative correlation between DMWS and the three indices showing significant $(p<0.05$ and $p<0.10)$ and nonsignificant $(p>0.10)$ relationships. Statistically significant trends at $p<0.10$ are in bold and $p<0.05$ are bold and in parentheses.

\begin{tabular}{|c|c|c|c|c|c|c|c|c|c|c|}
\hline & $\begin{array}{l}\text { Time } \\
\text { scale }\end{array}$ & Trend & Negative & $\begin{array}{c}\text { Negative } \\
\text { significant, } \\
p<0.05\end{array}$ & $\begin{array}{c}\text { Negative } \\
\text { significant, } \\
p<0.10\end{array}$ & $\begin{array}{c}\text { Negative } \\
\text { nonsignificant, } \\
p>0.10\end{array}$ & Positive & $\begin{array}{c}\text { Positive } \\
\text { significant, } \\
p<0.05\end{array}$ & $\begin{array}{c}\text { Positive } \\
\text { significant, } \\
p<0.10\end{array}$ & $\begin{array}{c}\text { Positive } \\
\text { nonsignificant, } \\
p>0.10\end{array}$ \\
\hline \multirow[t]{5}{*}{ AOI } & Annual & 0.05 & 91.3 & 30.7 & 43.4 & 56.6 & 8.7 & 0.0 & 1.5 & 98.5 \\
\hline & Winter & 0.11 & 84.6 & 16.1 & 28.1 & 71.9 & 15.4 & 0.0 & 0.8 & 99.2 \\
\hline & Spring & 0.09 & 93.2 & 22.5 & 34.1 & 65.9 & 6.8 & 0.0 & 0.0 & 100.0 \\
\hline & Summer & -0.04 & 64.0 & 14.1 & 27.5 & 72.5 & 36.0 & 3.2 & 7.1 & 92.9 \\
\hline & Autumn & -0.02 & 73.8 & 37.5 & 47.7 & 52.3 & 26.2 & 1.0 & 2.9 & 97.1 \\
\hline \multirow[t]{5}{*}{ WPI } & Annual & -0.09 & 13.2 & 1.0 & 4.9 & 95.1 & 86.8 & 40.1 & 52.6 & 47.4 \\
\hline & Winter & 0.15 & 55.8 & 1.6 & 3.9 & 96.1 & 44.2 & 8.4 & 12.5 & 87.5 \\
\hline & Spring & -0.14 & 19.9 & 1.3 & 3.2 & 96.8 & 80.1 & 31.0 & 39.0 & 61.0 \\
\hline & Summer & $(-0.35)$ & 84.6 & 38.0 & 53.0 & 47.0 & 15.4 & 17.5 & 24.2 & 75.8 \\
\hline & Autumn & -0.07 & 35.7 & 4.7 & 8.3 & 91.7 & 64.3 & 5.6 & 13.4 & 86.6 \\
\hline \multirow[t]{5}{*}{ SOI } & Annual & 0.08 & 63.8 & 10.1 & 17.3 & 82.7 & 36.2 & 3.5 & 7.4 & 92.6 \\
\hline & Winter & 0.08 & 94.6 & 25.7 & 50.5 & 49.5 & 5.4 & 4.8 & 7.1 & 92.9 \\
\hline & Spring & 0.05 & 57.5 & 16.3 & 22.1 & 77.9 & 42.5 & 17.5 & 29.3 & 70.7 \\
\hline & Summer & 0.02 & 41.9 & 1.8 & 4.6 & 95.4 & 58.1 & 2.2 & 3.1 & 96.9 \\
\hline & Autumn & 0.10 & 68.1 & 14.3 & 21.1 & 78.9 & 31.9 & 18.1 & 22.2 & 77.8 \\
\hline
\end{tabular}



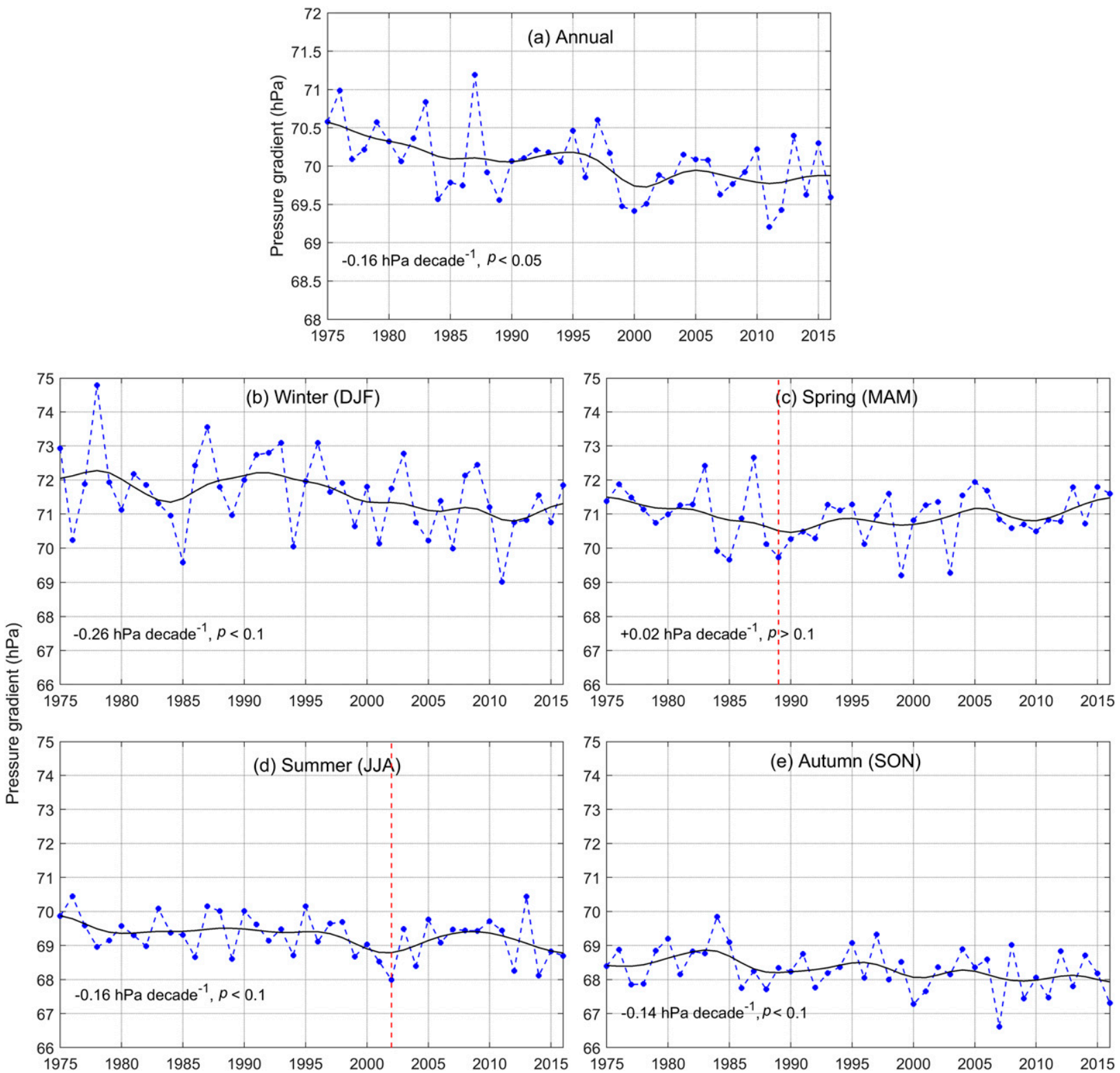

FIG. 8. Annual and seasonal horizontal pressure gradient trends between high and low latitudes (south-north direction) for 1975-2016. The 11-yr Gaussian low-pass filter (provided by the black solid line) highlights multidecadal variability. Decadal trends $\left(\mathrm{hPa}^{\mathrm{decade}}{ }^{-1}\right.$ ) of the horizontal pressure gradient, with the associated significance levels, are also displayed in each plot. Red dashed lines show the changepoint $(p>0.1)$ of the pressure gradient.

Moreover, in summer, widely declining geostrophic wind speed contrasted with the increased DMWS, except in northwest, northeast, and east China where geostrophic wind speed increased. Last, the most strongly declining geostrophic wind speed was found in north-central and northeast China in autumn, where DMWS also had the strongest declining trends (cf. Fig. 9 with Fig. 4e).

Moreover, the changes in the vertical transport of atmospheric momentum changes are represented by trends of both the $A$ index (Fig. 10) and vertical wind shear (Fig. 11) for China and its surroundings. Annually (Figs. 10a and 11a), almost all of northern and eastern China experienced widely negative trends of the $A$ index, varying from -1.5 to 0 decade $^{-1}$, while positive trends were found across the Tibetan Plateau $\left(0-1\right.$ decade $\left.^{-1}\right)$. Meanwhile, the weakened vertical wind shear (from -0.2 to $0 \mathrm{~m} \mathrm{~s}^{-1}$ decade $^{-1}$ ) was found in most parts of China, except a minor recovery $\left(0-0.1 \mathrm{~m} \mathrm{~s}^{-1}\right.$ decade $\left.^{-1}\right)$ in part of northwest China. Seasonally, the winter stratification instability decreased the strongest when compared with the other 
(a) Annual
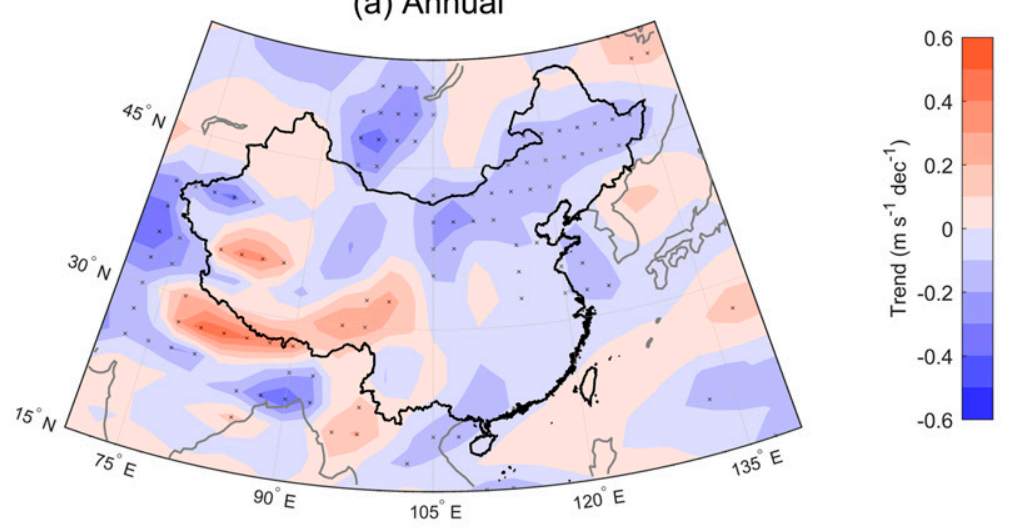

(b) Winter (DJF)

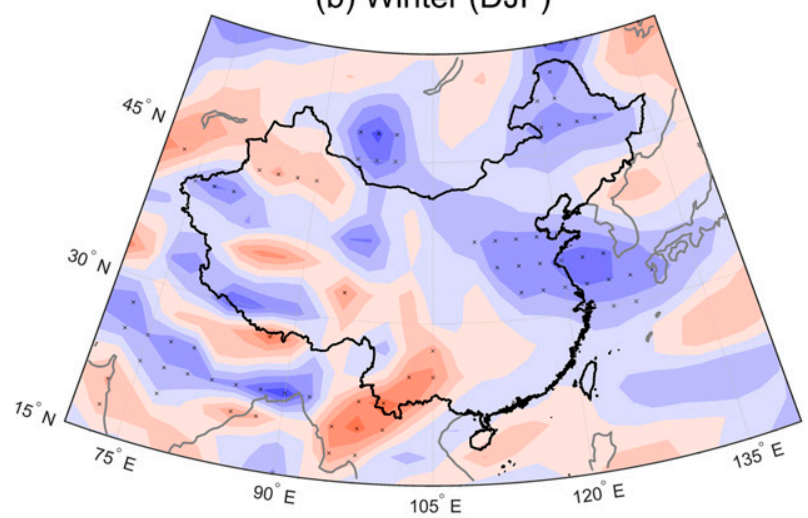

(d) Summer (JJA)

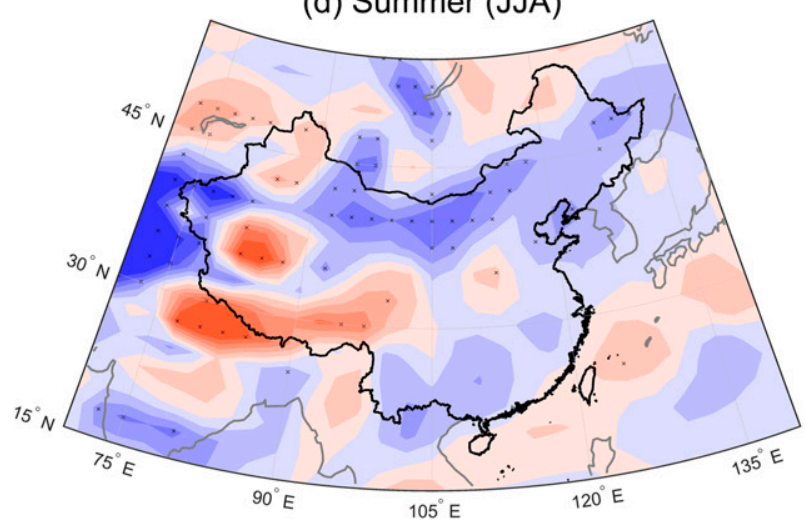

(c) Spring (MAM)

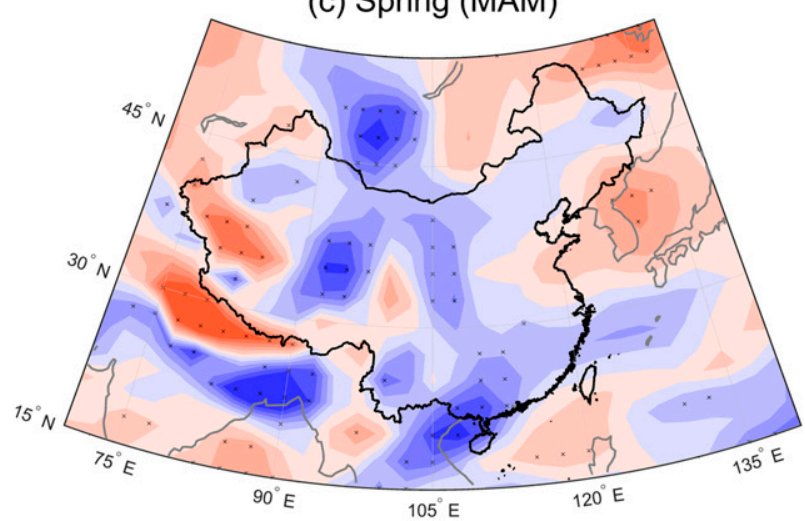

(e) Autumn (SON)

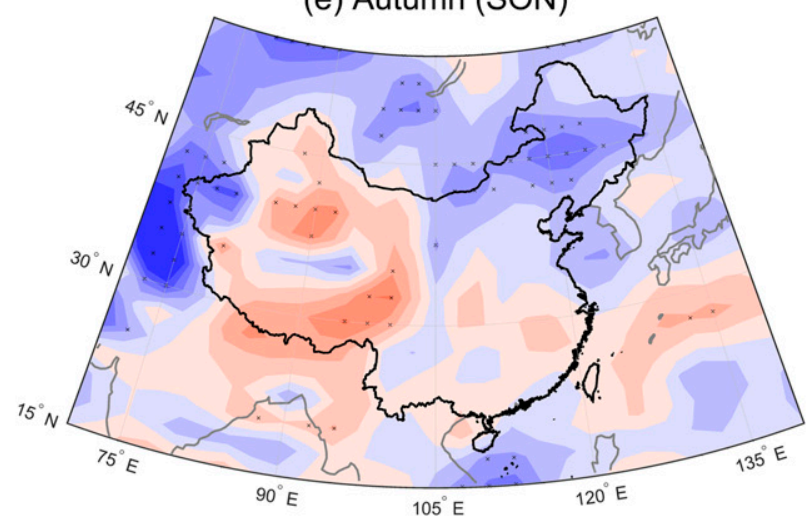

FIG. 9. Annual and seasonal spatial distribution of geostrophic wind speed trends $\left(\mathrm{m} \mathrm{s}^{-1} \mathrm{decade}^{-1}\right)$ across China and surroundings for 1975-2016. A small black " $\times$ " represents a $2.5^{\circ} \times 2.5^{\circ}$ grid cell with a significant trend at $p<0.05$.

seasons, with highest negative trend $\left(-2\right.$ decade $\left.^{-1}\right)$ in eastern China (Fig. 10b). At the same time, vertical wind shear (from -0.3 to $0 \mathrm{~m} \mathrm{~s}^{-1}$ decade $^{-1}$ ) widely declined in most part of China, barring parts of south and northwest China (Fig. 11b). Both patterns indicate the weakening of dynamic and thermal vertical momentum transport. Furthermore, spring (Figs. 10c and 11c) experienced the most strongly declining vertical wind shear (from -0.4 to $0 \mathrm{~m} \mathrm{~s}^{-1}$ decade $^{-1}$ ) in south and east China, and weakly increased vertical wind shear $\left(0-0.2 \mathrm{~m} \mathrm{~s}^{-1}\right.$ decade $\left.^{-1}\right)$ in northwest and northeast. Along with the similar pattern of stratification instability trends except northwest China, those showed agreement with the DMWS trends pattern (Fig. 4c). During summer (Figs. 10d and 11d), when DMWS generally increased across China (see Figs. 5d and 6d), 


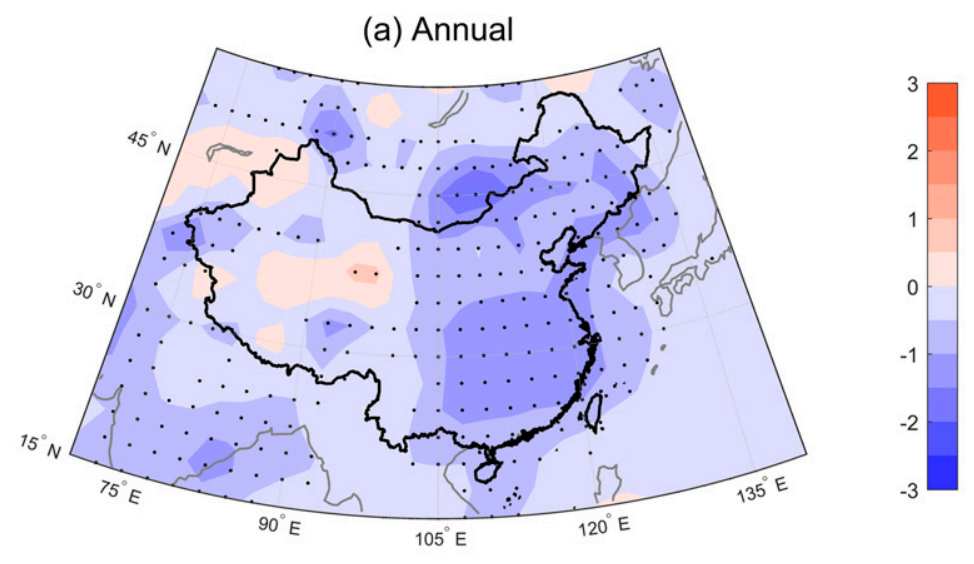

(b) Winter (DJF)

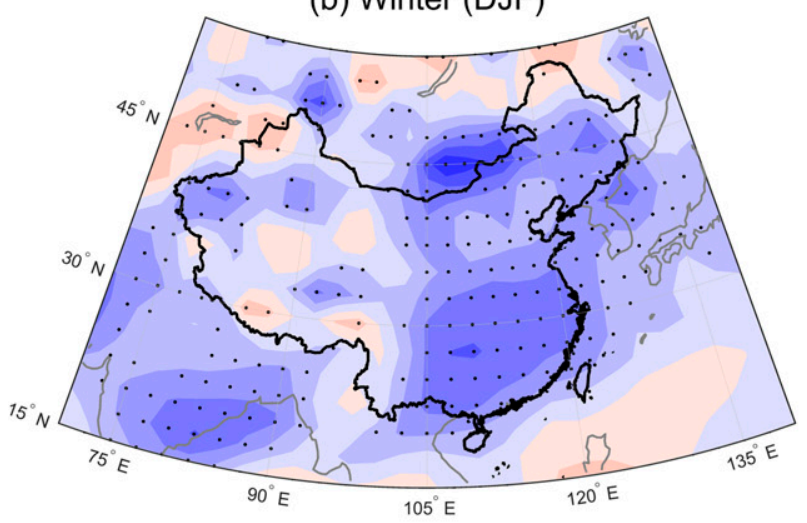

(d) Summer (JJA)

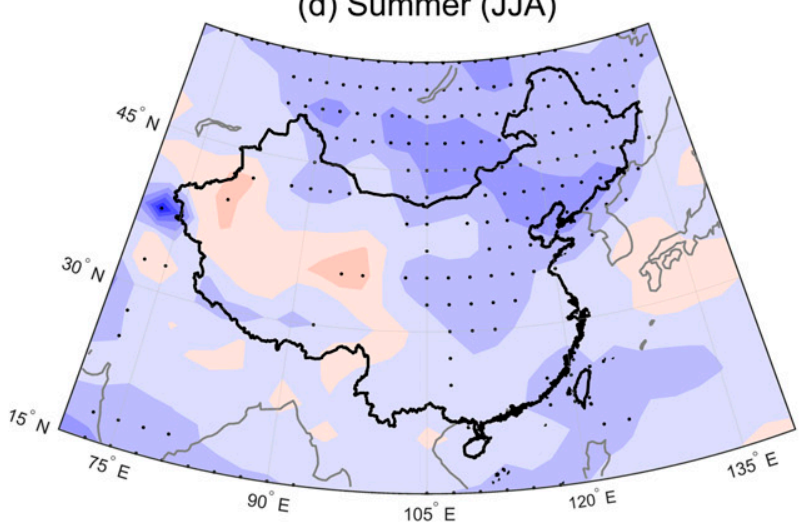

(c) Spring (MAM)

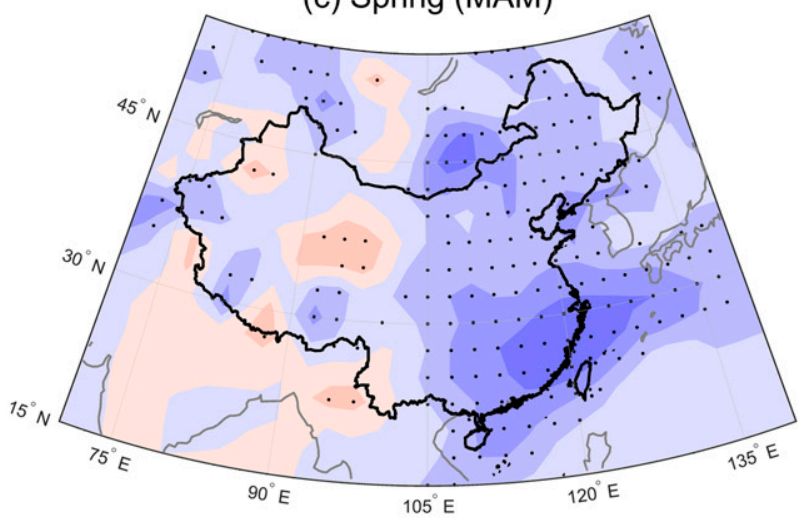

(e) Autumn (SON)

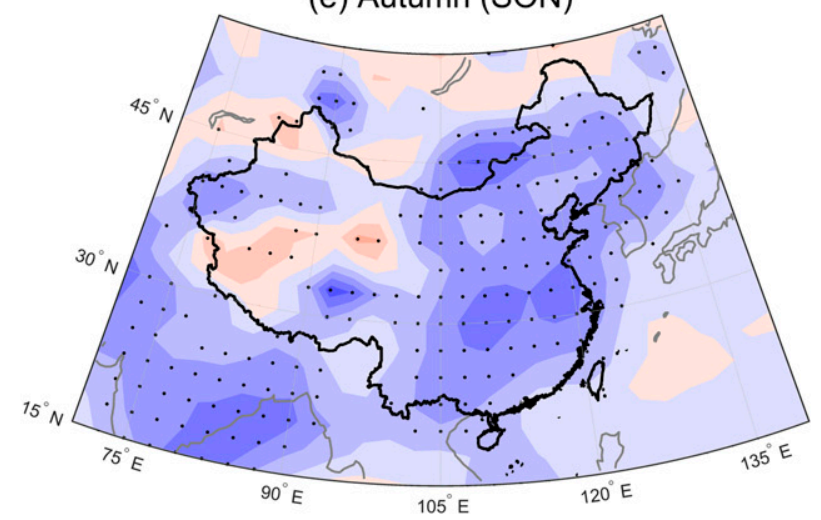

FIG. 10. Annual and seasonal spatial distribution of the sign and magnitude and associated statistical significance of the atmospheric thermal stratification (the $A$ index; dimensionless) trends across China and surroundings for 1975-2016. A small black " $\times$ " represents a $2.5^{\circ} \times 2.5^{\circ}$ grid cell with a significant trend at $p<0.05$.

decreased vertical wind shear occurred in northwest to northeast China and in south China (from -0.2 to $0 \mathrm{~m} \mathrm{~s}^{-1}$ decade $\left.^{-1}\right)$, while weak increased vertical wind shear $\left(0-0.1 \mathrm{~m} \mathrm{~s}^{-1}\right.$ decade $\left.^{-1}\right)$ occurred in northwest, southwest, and east China. In the meantime, atmospheric stratification instability decreased (from -1.5 to $0 \mathrm{decade}^{-1}$ ) in northern to eastern China (Fig. 11d). Those patterns indicate the weakened dynamic and thermal vertical momentum. Last, similar trends in stratification instability and vertical wind shear were detected in autumn (Figs. 10e and 11e), which demonstrated the weak dynamic and thermal vertical momentum transfer in the middle and low troposphere.

Seasonal trends in the frequency and intensity of ETCs around China are investigated (Fig. S6). A significant $(p<0.05)$ decrease in the ETC frequency 


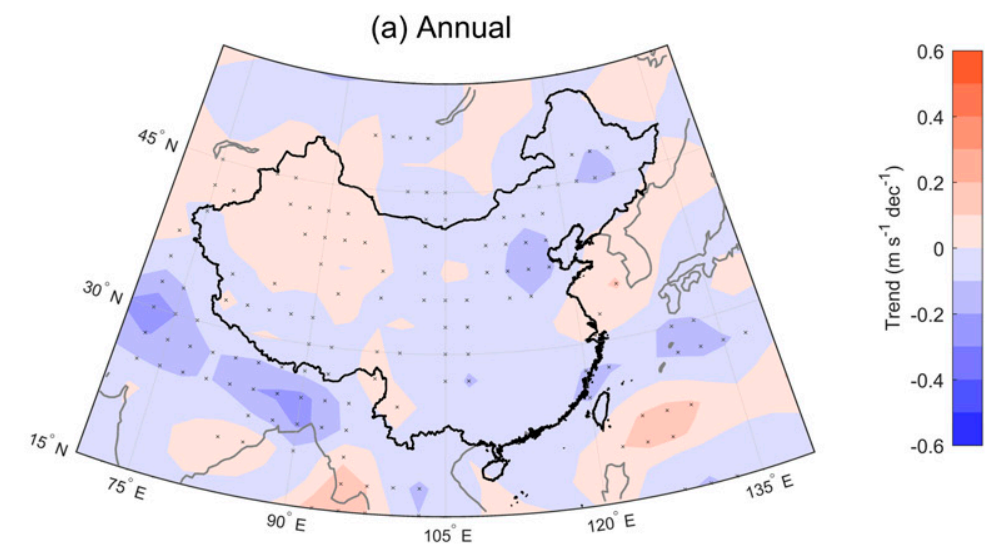

(b) Winter (DJF)

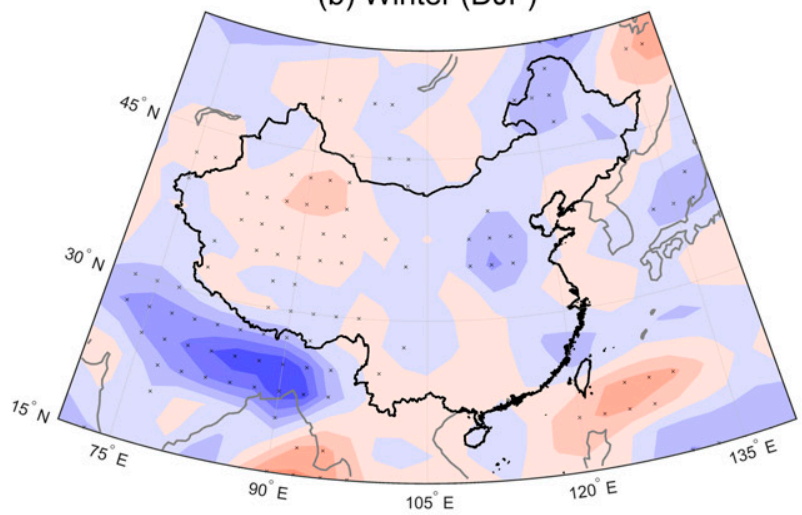

(d) Summer (JJA)

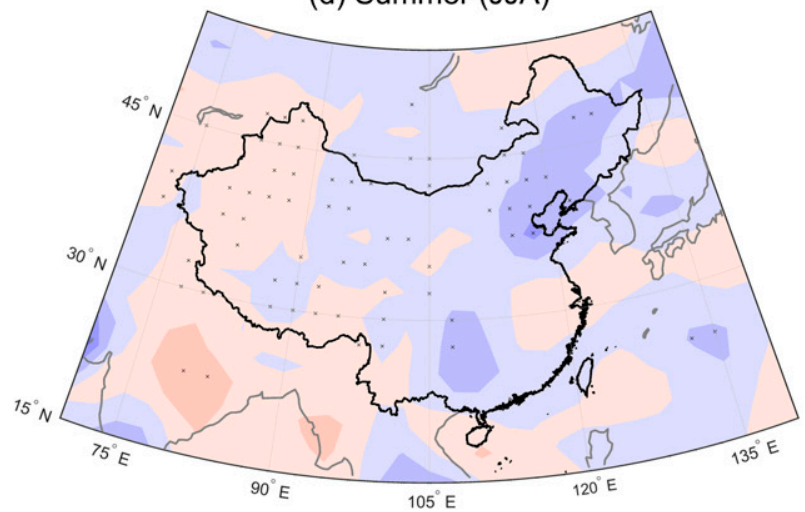

(c) Spring (MAM)

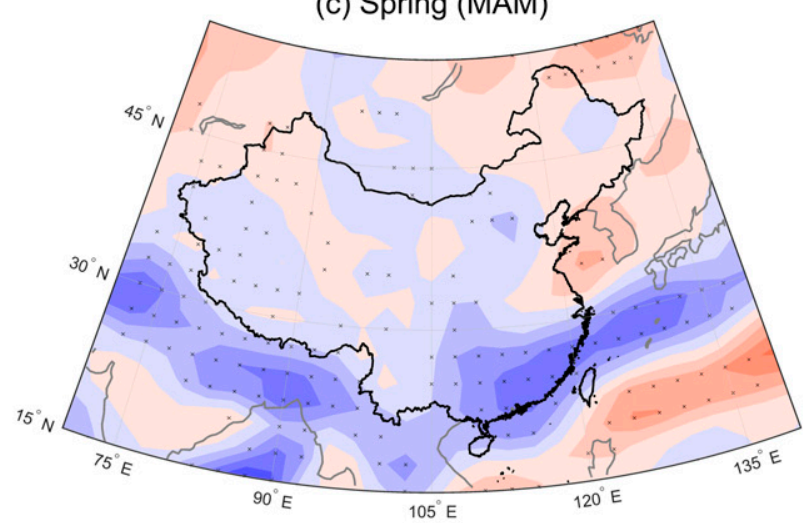

(e) Autumn (SON)

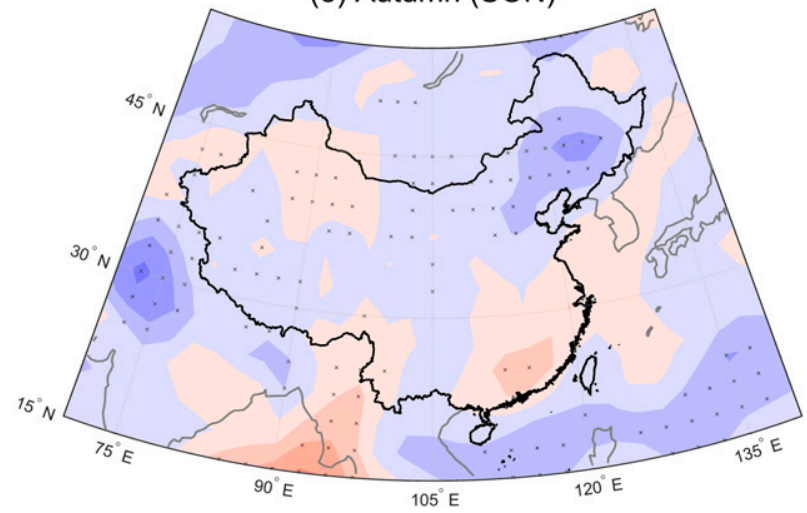

FIG. 11. Annual and seasonal spatial distribution of the vertical wind shear trends $\left(\mathrm{m} \mathrm{s}^{-1}\right.$ decade $\left.^{-1}\right)$ across China and surroundings for 1975-2016. A small black " $\times$ " represents a $2.5^{\circ} \times 2.5^{\circ}$ grid cell with a significant trend at $p<0.05$.

was observed over south and east China in spring, particularly in coastal regions of east China where significant $(p<0.05)$ declining DMWS was found in a large number of stations (Fig. 4c). This implies that the weakened spring DMWS in east coastal regions might be partly caused by the ETC frequency change. Autumn ETCs also showed weak negative trends in their frequency over east China coastal regions, which is again in line with the significant declined DMWS in coastal stations (Fig. 4e). However, the ETC frequency change in summer differs from DMWS trends. Although summer ETC activities have become weaker in north China, DMWS has increased (Fig. 4d). This result indicates that DMWS trends may not be simply explained by synoptic weather system changes. Unlike the frequency of ETCs, the intensity of ETCs exhibited a weak and not significant trend. Although significant trends were observed in summer over coastal regions of Shandong Peninsula, they were rather weak. 


\section{Discussion}

This study investigated multidecadal DMWS trends across China using 778 homogenized observed series for 1975-2016. Overall, annual DMWS displayed a significant $(p<0.05)$ decline of $-0.038 \mathrm{~m} \mathrm{~s}^{-1}$ decade $^{-1}$, with $71.5 \%$ of stations showing negative trends. As the study of extreme wind speed (e.g., daily maximum wind speed) changes only received little attention in the last 40 years (Wu et al. 2018), this new finding fills a research niche in regional climate research about daily maximum wind speed change. Moreover, this declining DMWS trend concords with the two main processes that are, in part, dependent on wind speed-namely, (i) widespread reductions in dust storms (e.g., Wang et al. 2017) and (ii) declining rates of pan evaporation (e.g., McVicar et al. 2012) — and also agree with China-specific studies that have reported declines of maximum wind speed (Jiang et al. 2010) in the last 4-5 decades (Table 1). Our findings reported a smaller magnitude of the DMWS trend than a previous study $\left(-1.46 \mathrm{~m} \mathrm{~s}^{-1}\right.$; Jiang et al. 2010). Further, we found that annual daily maximum 6-hourly wind speed (DM6WS) from NCEP-NCAR reanalysis nonsignificantly $(p<0.10)$ declined at $-0.005 \mathrm{~m} \mathrm{~s}^{-1}$ decade $^{-1}$, and displayed nonsignificant $(p>0.10)$ correlation with observed DMWS (Fig. S7). Spatially, annual DM6WS declined in south China, north-central China, and northeast China, which is in line with the negative trends of observed annual DMWS (Fig. 4a). Moreover, the areas showing positive trends in DM6WS are also consistent with the observed annual DMWS trends, except for east China, where DMWS decreased.

More interestingly, we detected distinct seasonal differences (Table 2): DMWS declined during the cold semester (October-March) yet increased during the warm semester (April-September). This marked seasonal/monthly pattern has not captured in seasonal DM6WS (Fig. S7), and not been reported in East Asia previously; for example, Jiang et al. (2010) reported a declining of DMWS in China for all seasons. Our contrasting results with Jiang et al. (2010) are likely due to three main reasons. First, our study covers a more recent period (1975-2016) than the previous study (1956-2004), and it is well known that the sign and magnitude of trends is sensitive to the study period considered (Troccoli et al. 2012). For instance, the recent DMWS trends might be affected by the recovery of global (Dunn et al. 2016; Zeng et al. 2019) and Chinese (Zhang et al. 2019) wind speed observed in the last decade. Second, a larger number of stations was used here (778 stations) than in Jiang et al. (2010) (536 stations). Besides, few stations recorded DMWS prior to the 1970s ( $<163$ stations; see Fig. S1), which means large uncertainties exist when calculating DMWS trends for the early period (e.g., 1956-70, with only 89 stations being available in 1956; see Fig. S1) due to the missing data. Third, and finally, a robust quality control and homogenization were applied herein, so that disturbances of nonclimatic factors (e.g., anemometer changes) to the observed DMWS data were removed (Azorin-Molina et al. 2014) when compared to the raw data used by Jiang et al. (2010). For instance, the China Meteorological Administration changed anemometers in most of the meteorological stations in both the 1960s and 1990s (Y. Li et al. 2018). Despite the fact that no previous China DMWS study applied a homogenization method (Table 1), similar spatial patterns were found herein when compared to those regional studies (Wang et al. 2015; Dong et al. 2018). Moreover, significant ( $p<$ 0.05 ) changepoints were also detected in our DMWS series, which might be associated with the decadal variability of large-scale atmospheric circulation as previous studies stated (e.g., Azorin-Molina et al. 2018b; Y. Li et al. 2018). The only other previous all-China DMWS study (Jiang et al. 2010) did not report such changepoints, and it is likely that our study, which extended theirs by 12 years (and used an additional 243 stations), is sensitive to the wind "recovery" (Dunn et al. 2016; Zeng et al. 2019; Zhang et al. 2019).

We also investigated the trends of DMWS anomalies for stations stratified into three elevation classes (LES, MES, and HES), as atmospheric dynamics are different within different elevation ranges (Azorin-Molina et al. 2018c). Similar to previous studies (McVicar et al. 2010; Lin et al. 2013) where mean daily wind speed was found to decrease faster at higher elevations areas compared to lower elevations, we reported a higher magnitude of negative trends of annual DMWS for HES, compared to MES and LES. While a recovery was found after 1998 for HES, this is in accordance with the increased wind speed in a high mountain station ( $3781 \mathrm{~m}$ MSL) in the Canary Islands (Azorin-Molina et al. 2018c). However, when looking at the trends seasonally, the decrease was larger for LES and MES in winter and the increase was higher for LES and MES in summer when compared to HES. In view of the limited knowledge on the long-term wind speed variability at high-elevation stations and at different geopotential heights of the troposphere, a next step in our research will be to assess and attribute wind speed variability among different elevations/altitudes (noting that "elevation" measures the vertical distance of the land surface above a datum and "altitude" is vertical distance above the land surface when an object is not in direct contact with the land surface; McVicar and Körner 2013). Unfortunately, high-elevation mountainous areas across China, like the Tibetan Plateau, lack long-term DMWS observations (Fig. 1), so large uncertainties about the DMWS variability in such complex-topographic regions persist. For this reason, we suggest further studies 
where climate model (McInnes et al. 2011) or satellite (Young and Ribal 2019) data outputs can be used to evaluate extreme wind speed variability.

Our analyses of the relationship of the observed DMWS anomalies with three teleconnection indices with synoptic features concord with previous studies on mean wind speed (Gong and Ho 2003; Lin et al. 2013; Y. Li et al. 2018). The positive phase of the AOI is concurrent with a weaker East Asian trough and an anomalous cyclonic flow over the Urals at the middle troposphere $(500 \mathrm{hPa}$; Gong et al. 2001); thus, the increase of annual and spring AOI partly explained the decrease of annual and spring DMWS. Further, negative SOI indicates below-average sea surface temperature in northwestern Pacific during winter, which maintained the anomalous anticyclonic circulation (W. Chen et al. 2013), weakening the pressure gradient between land and sea, and resulting in weak atmospheric circulation over China. More negative values of SOI since 1975 (Wang et al. 2013) may partly explain why DMWS decreased during winter. Negative phases of WPI were associated with below-average air temperatures over the lower latitudes of the northwestern Pacific during summer, which reflects the enhanced land-sea temperature gradient and pronounced zonal and meridional variations in the location and intensity of the East Asian jet stream. Choi and Moon (2012) also found that the negative WPI facilitated the movement of tropical cyclones in mainland China, and tropical cyclones induced more strong winds; thus, the decreased summer WP likely results in increased of DMWS over most of China. It is noted that AOI, SOI, and WPI have significant negative correlations with DMWS in China and MES, while differences occurred in LES and HES. This interesting finding implies that disparate atmospheric circulation motions might affect the DMWS in different regions (see Table S1). For instance, most HES are in southwest China, where DMWS dynamics are controlled by the southwest airflow (Yang et al. 2012). Consequently, DMWS dynamics in HES might be more sensitive to the large-scale atmospheric circulation changes (synoptic winds) that occurred in the free troposphere. Additionally, most MES are located from the northwest to north China, a region where DMWS dynamics are seemingly more affected by strong westerly winds (Han et al. 2008). LES are widely distributed from northeast to south China and within the boundary layer, and thus DMWS are mainly driven by thermal differences between the land and adjacent oceans and the effect of local phenomena such as sea breezes or other local winds (Wu et al. 2016). We suggest that future studies quantify the impacts of different atmospheric circulations on DMWS in different regions and seasons, by implementing sensitive experiments in state-of-the-art climate models.
The rapid warming in high and middle latitudes of the Eurasian continent observed in the last few decades (IPCC 2013) could weaken the meridional temperature gradient (Guo et al. 2011; Lin et al. 2013). This will modify large-scale pressure gradient through thermal adaption (Lin et al. 2013; Y. Li et al. 2018), which consequently affects DMWS dynamics. For instance, the variability of pressure gradient between high and low latitudes shows an agreement with the DMWS changes except for summer (see Figs. 5 and 8). Further, regional differences of the pressure gradient force were revealed by geostrophic wind changes, which indicated weakened high-level (i.e., $850 \mathrm{hPa}$ ) winds and shows partial agreement with DMWS changes. Moreover, we also investigated the change of vertical transport of atmospheric momentum represented by atmospheric thermal stratification instability (Fig. 10) and vertical wind shear (Fig. 11). Overall, we found that the atmospheric thermal stratification instability and vertical wind shear declined from northern China to southeast China. This pattern indicated weakened vertical momentum transport from the middle and lower troposphere to surface, which is also supported by the decreased convective available potential energy identified previously (Q. Zhang et al. 2017; Cai et al. 2017). Additionally, decreasing ETC frequencies over south China in spring and over north China in autumn were also consistent with the enhanced static stability (Lee et al. 2019) that weakening DMWS identified herein. It would be interesting to determine if similar drivers of DMWS occurred for other major Northern Hemisphere landmasses such as Europe, North America, and central Asia; however, a lack of comprehensive studies exists on drivers controlling DMWS variability and trends.

As China is strongly influenced by monsoons (from north and south), the changes in the East Asian monsoon should influence the China's DMWS dynamics. The decreased EAWS $(-0.11, p>0.10)$ and EASM $(-0.20, p<0.05)$ for $1975-2016$ revealed the weakening in large-scale atmospheric circulation, which concords with the decreased atmospheric circulation change and substantially weakened DMWS annually and in winter (Xu et al. 2006; Wu et al. 2016). Increasing surface roughness (Vautard et al. 2010; Wever 2012) and urbanization ( $\mathrm{Z}$. Li et al. 2018) have also played a role in weakening winds. However, this suggests that the factors controlling the increasing DMWS trend in summer are complex, being partly driven by local weather systems. For instance, surface wind speed could reach the maximum in the afternoon with dominant sea breezes, local winds, and strong local convection (Yu et al. 2009). Moreover, the increase in summer winds has been observed in other midlatitude regions around the world, 
such as South Korea (Kim and Paik 2015), Spain and Portugal (Azorin-Molina et al. 2016), and Saudi Arabia (Azorin-Molina et al. 2018b). Kim and Paik (2015) showed that increased summer mean wind speed in South Korea is caused by the partial intrusion of a warmer air mass that increased spatial variance of nearsurface temperature, which regulates the local pressure gradient force. Azorin-Molina et al. (2016) suggested that positive trends of summer and autumn wind gust in Spain and Portugal might induced by soil moisture depletion and other physical mechanisms that reinforced the Iberian thermal low, thereby strengthening local wind circulations. Thus more uncertain physical causes likely govern the summer DMWS increases, which deserve further investigation, including attribution studies. We encourage other studies to determine specific physical drivers govern summer DMWS increases elsewhere.

\section{Conclusions}

To summarize, our main findings are as follows:

1) Annual daily maximum wind speed (DMWS) declined significantly $(p<0.05)$ at $-0.038 \mathrm{~m} \mathrm{~s}^{-1}$ decade $^{-1}$ for 778 stations across China from 1975-2016, with a distinct seasonality in DMWS trends: whereas DMWS declined in winter $\left(-0.355 \mathrm{~m} \mathrm{~s}^{-1}\right.$ decade $\left.^{-1}, p<0.05\right)$ and autumn $\left(-0.108 \mathrm{~m} \mathrm{~s}^{-1}\right.$ decade $\left.^{-1}, p<0.05\right)$, it increased in summer $\left(+0.272 \mathrm{~m} \mathrm{~s}^{-1}\right.$ decade $^{-1}, p<$ $0.05)$ and spring $\left(+0.032 \mathrm{~m} \mathrm{~s}^{-1}\right.$ decade $\left.^{-1}, p>0.10\right)$.

2) A stronger magnitude of negative trends of annual DMWS was found for the high-elevation stations $\left(-0.067 \mathrm{~m} \mathrm{~s}^{-1}\right.$ decade $\left.^{-1}, p<0.05\right)$ than for the lowelevation $\left(-0.038 \mathrm{~m} \mathrm{~s}^{-1}\right.$ decade $\left.^{-1}, p<0.05\right)$ and midelevation stations $\left(-0.029 \mathrm{~m} \mathrm{~s}^{-1}\right.$ decade $\left.^{-1}, p>0.10\right)$.

3) Large-scale atmospheric circulation modes play a key role in modulating DMWS variability: 1) the Arctic Oscillation negatively influences the annual, spring and autumn DMWS and explains the highest amount of DMWS variance $(24.1 \%, 14.2 \%$, and $13.3 \%$, respectively), 2) the Southern Oscillation displays a strong positive correlation and explains the highest variance in winter $(11.6 \%)$, and 3 ) the west Pacific mode negatively modulates DMWS explaining most variance in summer (14.3\%).

4) Five interplaying processes are likely controlling the detected DMWS changes: (i) varied surface horizontal pressure gradient (from -0.24 to $+0.02 \mathrm{hPa} \mathrm{decade}^{-1}$ ) between high and low latitudes and (ii) regional pressure gradient force (i.e., geostrophic wind speed at $850 \mathrm{hPa}$; from -0.6 to $+0.6 \mathrm{~m} \mathrm{~s}^{-1}$ decade $^{-1}$ ) showed the overall weakened horizontal airflow; both (iii) atmospheric stratification thermal instability (from -3 to +1.5 decade $^{-1}$ ) and (iv) vertical wind shear (from -0.4 to $+0.2 \mathrm{~m} \mathrm{~s}^{-1}$ decade $^{-1}$ ) widely decreased over most of China, revealing the universally decreased vertical momentum transport; and (v) extratropical cyclone occurrences are less frequent (from -0.3 to 0 month decade ${ }^{-1}$ ), particularly for coastal regions of east China.

Acknowledgments. This study was supported by the National Natural Science Foundation of China (Grant 41621061), the National Key Research and Development Program-Global Change and Mitigation Project (Grant 2016YFA0602404), funding from STINT (CH2015-6226), and the European Union's Horizon 2020 research and innovation program under the Marie Skłodowska-Curie grant agreement 703733 (STILLING project). This work has been also supported by the VR project (2017-03780) funded by the Swedish Research Council and Ramon y Cajal fellowship (RYC-2017-22830) and Grant RTI2018095749-A-I00 (MCIU/AEI/FEDER, UE). The authors wish to acknowledge the editor and the anonymous reviewers for their detailed and helpful comments to the original manuscript.

\section{REFERENCES}

Alexandersson, H., 1986: A homogeneity test applied to precipitation data. Int. J. Climatol., 6, 661-675, https://doi.org/ 10.1002/joc.3370060607.

Azorin-Molina, C., and Coauthors, 2014: Homogenization and assessment of observed near-surface wind speed trends over Spain and Portugal, 1961-2011. J. Climate, 27, 3692-3712, https://doi.org/10.1175/JCLI-D-13-00652.1.

, J. A. Guijarro, T. R. McVicar, S. M. Vicente-Serrano, D. Chen, S. Jerez, and F. Espírito-Santo, 2016: Trends of daily peak wind gusts in Spain and Portugal, 1961-2014. J. Geophys. Res. Atmos., 121, 1059-1078, https://doi.org/10.1002/2015JD024485.

—_, R. J. H. Dunn, C. A. Mears, P. Berrisford, and T. R. McVicar, 2017: Global climate; atmospheric circulation surface winds [in "State of the Climate in 2016"]. Bull. Amer. Meteor. Soc., 98 (8), S37-S39, https://doi.org/10.1175/ 2017BAMSStateoftheClimate.1.

_, J. Asin, T. R. McVicar, L. Minola, J. I. Lopez-Moreno, S. M. Vicente-Serrano, and D. Chen, 2018a: Evaluating anemometer drift: A statistical approach to correct biases in wind speed measurement. Atmos. Res., 203, 175-188, https://doi.org/10.1016/ j.atmosres.2017.12.010.

_ S. Rehman, J. A. Guijarro, T. R. McVicar, L. Minola, D. Chen, and S. M. Vicente-Serrano, 2018b: Recent trends in wind speed across Saudi Arabia, 1978-2013: A break in the stilling. Int. J. Climatol., 38, e966-e984, https://doi.org/10.1002/joc.5423.

—, M. Menendez, T. R. McVicar, A. Acevedo, S. M. VicenteSerrano, E. Cuevas, L. Minola, and D. Chen, 2018c: Wind speed variability over the Canary Islands, 1948-2014: Focusing on trend differences at the land-ocean interface and below-above the trade-wind inversion layer. Climate Dyn., 50, 4061-4081, https://doi.org/10.1007/s00382-017-3861-0.

, R. Dunn, C. Mears, P. Berrisford, T. McVicar, and J. P. Nicolas, 2019: Surface winds [in "State of the Climate in 
2018']. Bull. Amer. Meteor. Soc., 100 (9), S43-S45, https:// doi.org/10.1175/2019BAMSStateoftheClimate.1.

Barnston, A. G., and R. E. Livezey, 1987: Classification, seasonality and persistence of low-frequency atmospheric circulation patterns. Mon. Wea. Rev., 115, 1083-1126, https://doi.org/ 10.1175/1520-0493(1987)115<1083:CSAPOL > 2.0.CO;2.

Bichet, A., M. Wild, D. Folini, and C. Schär, 2012: Causes for decadal variations of wind speed over land: Sensitivity studies with a global climate model. Geophys. Res. Lett., 39, L11701, https://doi.org/10.1029/2012GL051685.

Brázdil, R., J. Hostýnek, L. Rezníčková, P. Zahradníček, R. Tolasz, P. Dobrovolný, and P. Štěpánek, 2017: The variability of maximum wind gusts in the Czech Republic between 1961 and 2014. Int. J. Climatol., 37, 1961-1978, https://doi.org/10.1002/joc.4827.

Cai, W., K. Li, H. Liao, H. Wang, and L. Wu, 2017: Weather conditions conducive to Beijing severe haze more frequent under climate change. Nat. Climate Change, 7, 257-262, https:// doi.org/10.1038/nclimate3249.

Chen, B., H. Qiu, and Q. Zhao, 2010: The spatial and temporal distribution of annual maximum wind speed in Jiangsu province and analyses on its abrupt change (in Chinese). Sci. Meteor. Sin., 30, 214-220.

Chen, L., D. Li, and S. C. Pryor, 2013: Wind speed trends over China: Quantifying the magnitude and assessing causality. Int. J. Climatol., 33, 2579-2590, https://doi.org/10.1002/joc.3613.

Chen, W., X. Lan, L. Wang, and Y. Ma, 2013: The combined effects of the ENSO and the Arctic oscillation on the winter climate anomalies in East Asia. Chin. Sci. Bull., 58, 1355-1362, https:// doi.org/10.1007/s11434-012-5654-5.

Cho, H.-O., S.-W. Son, and D.-S. R. Park, 2018: Springtime extratropical cyclones in Northeast Asia and their impacts on longterm precipitation trends. Int. J. Climatol., 38, 4043-4050, https://doi.org/10.1002/joc.5543.

Choi, K.-S., and I.-J. Moon, 2012: Influence of the western Pacific teleconnection pattern on western North Pacific tropical cyclone activity. Dyn. Atmos. Oceans, 57, 1-16, https://doi.org/ 10.1016/j.dynatmoce.2012.04.002.

Cui, X., H. Sun, Z. Dong, Z. Liu, C. Li, Z. Zhang, X. Li, and L. Li, 2019: Temporal variation of the wind environment and its possible causes in the $\mathrm{Mu}$ Us Dunefield of northern China, 1960-2014. Theor. Appl. Climatol., 135, 1017-1029, https:// doi.org/10.1007/S00704-018-2417-5.

Cusack, S., 2013: A 101 year record of windstorms in the Netherlands. Climatic Change, 116, 693-704, https://doi.org/ 10.1007/s10584-012-0527-0.

Dee, D. P., and Coauthors, 2011: The ERA-Interim reanalysis: Configuration and performance of the data assimilation system. Quart. J. Roy. Meteor. Soc., 137, 553-597, https://doi.org/ $10.1002 /$ qj. 828 .

Dong, X., C. Qiu, J. Li, and H. Liu, 2018: Spatial and temporal distribution of terrestrial annual maximum wind speed in Shandong from 1981 to 2016 (in Chinese, with English abstract). J. Mar. Meteor., 38, 87-95.

Dunn, R. J. H., C. Azorin-Molina, C. A. Mears, P. Berrisford, and T. R. McVicar, 2016: Global climate; atmospheric circulation surface winds [in "State of the Climate in 2015"]. Bull. Amer. Meteor. Soc., 97 (8), S38-S40, https://doi.org/10.1175/2016BAMSStateoftheClimate.1.

Fujii, T., 2007: On geographical distributions and decadal changes of the annual maximum wind speeds caused by typhoons in Japan (in Japanese, with English abstract). J. Nat. Disaster Sci., 26, 267-277.

Gardiner, B., P. Berry, and B. Moulia, 2016: Review: Wind impacts on plant growth, mechanics and damage. Plant Sci., 245, 94118, https://doi.org/10.1016/j.plantsci.2016.01.006.
Gavit, P., R. Tholmer, and Y. Baddour, 2009: Use of change-point analysis for process monitoring and control: A better method for trend analysis than CUSUM and control charts. Biopharm Int., 22, 46-55, http://www.biopharminternational.com/usechange-point-analysis-process-monitoring-and-control.

Gilbert, R. O., 1987: Sen's nonparametric estimator of slope. Statistical Methods for Environmental Pollution Monitoring, Wiley, 217-219.

Gong, D., and C.-H. Ho, 2003: Arctic Oscillation signals in the East Asian summer monsoon. J. Geophys. Res., 108, 4066, https:// doi.org/10.1029/2002JD002193.

_, S. Wang, and J. Zhu, 2001: East Asian winter monsoon and Arctic oscillation. Geophys. Res. Lett., 28, 2073-2076, https:// doi.org/10.1029/2000GL012311.

Grise, K. M., S. Son, and J. R. Gyakum, 2013: Intraseasonal and interannual variability in North American storm tracks and its relationship to equatorial Pacific variability. Mon. Wea. Rev., 141, 3610-3625, https://doi.org/10.1175/MWR-D-12-00322.1.

Guijarro, J. A., 2017: Daily series homogenization and gridding with Climatol v.3. Proc. Ninth Seminar for Homogenization and Quality Control in Climatological Databases and Fourth Conf. on Spatial Interpolation Techniques in Climatology and Meteorology, Budapest, Hungary, WMO, 175-180.

Guo, H., M. Xu, and Q. Hu, 2011: Changes in near-surface wind speed in China: 1969-2005. Int. J. Climatol., 31, 349-358, https://doi.org/10.1002/joc.2091.

Guo, X., W. Ding, Q. Li, and T. Zeng, 2015: Climate characteristics of the maximum wind speed in northeastern margin of Qilian Mountains (in Chinese, with English abstract). Arid Land Geogr., 36, 446-453.

Han, Y. M., Z. W. Han, J. J. Cao, J. C. Chow, J. G. Watson, Z. S. An, S. X. Liu, and R. J. Zhang, 2008: Distribution and origin of carbonaceous aerosol over a rural high-mountain lake area, northern China and its transport significance. Atmos. Environ., 42, 2405-2414, https://doi.org/10.1016/j.atmosenv.2007.12.020.

Hoskins, B. J., and K. I. Hodges, 2002: New perspectives on the Northern Hemisphere winter storm tracks. J. Atmos. Sci., 59, 1041-1061, https://doi.org/10.1175/1520-0469(2002)059<1041: $\mathrm{NPOTNH}>2.0 . \mathrm{CO} ; 2$.

Huang, M., Z. Gao, S. Miao, and X. Xu, 2016: Characteristics of sea breezes over the Jiangsu coastal area. China. Int. J. Climatol., 36, 3908-3916, https://doi.org/10.1002/joc.4602.

IPCC, 2013: Climate Change 2013: The Physical Science Basis. Cambridge University Press, 1535 pp, https://doi.org/10.1017/ CBO9781107415324.

Jiang, Y., Y. Luo, Z. Zhao, and S. Tao, 2010: Changes in wind speed over China during 1956-2004. Theor. Appl. Climatol., 99, 421430, https://doi.org/10.1007/s00704-009-0152-7.

,$- \ldots$, and,- 2013 : Maximum wind speed changes over China. Acta Meteor. Sin., 27, 63-74, https://doi.org/10.1007/ s13351-013-0107-x.

Kalnay, E., and Coauthors, 1996: The NCEP/NCAR 40-Year Reanalysis Project. Bull. Amer. Meteor. Soc., 77, 437-471, https://doi.org/ 10.1175/1520-0477(1996)077<0437:TNYRP > 2.0.CO;2.

Karnauskas, K. B., J. K. Lundquist, and L. Zhang, 2018: Southward shift of the global wind energy resource under high carbon dioxide emissions. Nat. Geosci., 11, 38-43, https://doi.org/ 10.1038/s41561-017-0029-9.

Kendall, M. G., and J. D. Gibbons, 1990: Rank Correlation Methods. Oxford University Press, 272 pp.

Kim, J. C., and K. Paik, 2015: Recent recovery of surface wind speed after decadal decrease: A focus on South Korea. Climate Dyn., 45, 1699-1712, https://doi.org/10.1007/s00382-015-2546-9. 
Klink, K., 2015: Seasonal patterns and trends of fastest 2-min winds at coastal stations in the conterminous USA. Int. J. Climatol., 35, 4167-4175, https://doi.org/10.1002/joc.4275.

Kruger, A. C., A. M. Goliger, J. V. Retief, and S. Sekele, 2010: Strong wind climatic zones in South Africa. Wind Struct., 13, 37-55, https://doi.org/10.12989/was.2010.13.1.037.

Lee, J., S.-W. Son, H.-O. Cho, J. Kim, D.-H. Cha, J. R. Gyakum, and D. Chen, 2019: Extratropical cyclones over East Asia: Climatology, seasonal cycle, and long-term trend. Climate Dyn., 54, 1131-1144, https://doi.org/10.1007/s00382-019-05048-w

Li, J., Z. Wu, Z. Jiang, and J. He, 2010: Can global warming strengthen the East Asian summer monsoon? J. Climate, 23, 6696-6705, https://doi.org/10.1175/2010JCLI3434.1.

Li, Y., Y. Chen, Z. Li, and G. Fang, 2018: Recent recovery of surface wind speed in northwest China. Int. J. Climatol., $\mathbf{3 8}$, 4445-4458, https://doi.org/10.1002/JOC.5679.

Li, Z., L. Song, H. Ma, J. Xiao, K. Wang, and L. Chen, 2018: Observed surface wind speed declining induced by urbanization in East China. Climate Dyn., 50, 735-749, https://doi.org/ 10.1007/s00382-017-3637-6.

Lin, C., K. Yang, J. Qin, and R. Fu, 2013: Observed coherent trends of surface and upper-air wind speed over China since 1960. J. Climate, 26, 2891-2903, https://doi.org/10.1175/JCLI-D-12-00093.1.

Liu, J., C. Y. Gao, J. Ren, Z. Gao, H. Liang, and L. Wang, 2018: Wind resource potential assessment using a long term tower measurement approach: A case study of Beijing in China. J. Clean. Prod., 174, 917-926, https://doi.org/10.1016/ j.jclepro.2017.10.347.

McInnes, K. L., T. A. Erwin, and J. M. Bathols, 2011: Global climate model projected changes in $10 \mathrm{~m}$ wind speed and direction due to anthropogenic climate change. Atmos. Sci. Lett., 12, 325-333, https://doi.org/10.1002/asl.341.

McVicar, T. R., and C. Körner, 2013: On the use of elevation, altitude, and height in the ecological and climatology literature. Oecologia, 171, 335-337, https://doi.org/10.1007/s00442-012-2416-7.

_ , T. G. Van Niel, L. T. Li, M. L. Roderick, D. P. Rayner, L. Ricciardulli, and R. J. Donohue, 2008: Wind speed climatology and trends for Australia, 1975-2006: Capturing the stilling phenomenon and comparison with near-surface reanalysis output. Geophys. Res. Lett., 35, L20403, https:// doi.org/10.1029/2008GL035627.

— - — M. L. Roderick, L. T. Li, X. G. Mo, N. E. Zimmermann, and D. R. Schmatz, 2010: Observational evidence from two mountainous regions that near-surface wind speeds are declining more rapidly at higher elevations than lower elevations: 1960-2006. Geophys. Res. Lett., 37, L06402, https:// doi.org/10.1029/2009GL042255.

_ , and Coauthors, 2012: Global review and synthesis of trends in observed terrestrial near-surface wind speeds: Implications for evaporation. J. Hydrol., 416-417, 182-205, https://doi.org/ 10.1016/j.jhydrol.2011.10.024.

Minola, L., C. Azorin-Molina, and D. Chen, 2016: Homogenization and assessment of observed near-surface wind speed trends across Sweden, 1956-2013. J. Climate, 29, 7397-7415, https:// doi.org/10.1175/JCLI-D-15-0636.1.

Neumayer, E., T. Plümper, and F. Barthel, 2014: The political economy of natural disaster damage. Global Environ. Change, 24, 8-19, https://doi.org/10.1016/j.gloenvcha.2013.03.011.

Peters, G. P., R. M. Andrew, J. G. Canadell, S. Fuss, R. B. Jackson, J. I. Korsbakken, C. Le Quéré, and N. Nakicenovic, 2017: Key indicators to track current progress and future ambition of the Paris Agreement. Nat. Climate Change, 7, 118-122, https:// doi.org/10.1038/nclimate3202.
Pinard, J. P., 2007: Wind climate of the Whitehorse area. Arctic, 60, 227-237, https://doi.org/10.14430/arctic215.

Roderick, M. L., L. D. Rotstayn, G. D. Farquhar, and M. T. Hobbins, 2007: On the attribution of changing pan evaporation. Geophys. Res. Lett., 34, L17403, https://doi.org/10.1029/ 2007GL031166.

Rogelj, J., and Coauthors, 2016: Paris Agreement climate proposals need a boost to keep warming well below $2^{\circ} \mathrm{C}$. Nature, 534, 631-639, https://doi.org/10.1038/nature18307.

Ropelewski, C. F., and P. D. Jones, 1987: An extension of the Tahiti-Darwin Southern Oscillation index. Mon. Wea. Rev., 115, 2161-2165, https://doi.org/10.1175/1520-0493(1987)115<2161: AEOTTS $>2.0 . \mathrm{CO} ; 2$.

Segovia, C., J. D. Gómez, P. Gallardo, F. J. Lozano, and C. Asensio, 2017: Soil nutrients losses by wind erosion in a citrus crop at southeast Spain. Eurasian Soil Sci., 50, 756-763, https://doi.org/10.1134/S1064229317060114.

Shi, P., G. Zhang, F. Kong, and Q. Ye, 2015: Wind speed change regionalization in China (1961-2012). Adv. Climate Change Res., 6, 151-158, https://doi.org/10.1016/j.accre.2015.09.006.

,,--- D. Chen, C. Azorin-Molina, and J. A. Guijarro, 2019: Variability of winter haze over the Beijing-TianjinHebei region tied to wind speed in the lower troposphere and particulate sources. Atmos. Res., 215, 1-11, https://doi.org/ 10.1016/j.atmosres.2018.08.013.

Thompson, D. W., and J. M. Wallace, 1998: The Arctic Oscillation signature in the wintertime geopotential height and temperature fields. Geophys. Res. Lett., 25, 1297-1300, https://doi.org/ 10.1029/98GL00950.

Tobin, I., P. Berrisford, R. J. H. Dunn, R. Vautard, and T. R. McVicar, 2014: Global climate; atmospheric circulation land surface wind speed [in "State of the Climate in 2013"]. Bull. Amer. Meteor. Soc., 95 (7), S28-S29, https://doi.org/10.1175/ 2014BAMSStateoftheClimate.1.

Troccoli, A., K. Muller, P. Coppin, R. Davy, C. Russell, and A. L. Hirsch, 2012: Long-term wind speed trends over Australia. J. Climate, 25, 170-183, https://doi.org/10.1175/ 2011JCLI4198.1.

Vautard, R., J. Cattiaux, P. Yiou, J. N. Thépaut, and P. Ciais, 2010: Northern Hemisphere atmospheric stilling partly attributed to an increase in surface roughness. Nat. Geosci., 3, 756-761, https://doi.org/10.1038/ngeo979.

Wallace, J. M., and D. S. Gutzler, 1981: Teleconnections in the geopotential height field during the Northern Hemisphere winter. Mon. Wea. Rev., 109, 784-812, https://doi.org/10.1175/ 1520-0493(1981)109<0784:TITGHF>2.0.CO;2.

Wan, H., X. L. Wang, and V. R. Swail, 2010: Homogenization and trend analysis of Canadian near-surface wind speeds. J. Climate, 23, 1209-1225, https://doi.org/10.1175/2009JCLI3200.1.

Wang, B., F. Hu, and X. Cheng, 2011: Wind gust and turbulence statistics of typhoons in South China. Acta Meteor. Sin., 25, 113-127, https://doi.org/10.1007/s13351-011-0009-8.

Wang, C., J. Zhou, S. Zhou, Y. Zhang, and G. Zhang, 2015: Distribution characteristics of wind in Anhui Province during 1981-2012 (in Chinese). J. Arid Meteor., 33, 236-243.

Wang, H., and S. He, 2012: Weakening relationship between East Asian winter monsoon and ENSO after mid-1970s. Chin. Sci. Bull., 57, 3535-3540, https://doi.org/10.1007/ s11434-012-5285-x.

, - - and J. Liu, 2013: Present and future relationship between the East Asian winter monsoon and ENSO: Results of CMIP5. J. Geophys. Res. Oceans, 118, 5222-5237, https:// doi.org/10.1002/jgrc.20332. 
Wang, R., and Coauthors, 2017: Variation of strong dust storm events in Northern China during 1978-2007. Atmos. Res., 183, 166-172, https://doi.org/10.1016/j.atmosres.2016.09.002.

Wentz, F. J., L. Ricciardulli, K. Hilburn, and C. Mears, 2007: How much more rain will global warming bring? Science, 317, 233235, https://doi.org/10.1126/science.1140746.

Wever, N., 2012: Quantifying trends in surface roughness and the effect on surface wind speed observations. J. Geophys. Res., 117, D11104, https://doi.org/10.1029/2011JD017118.

Wu, J., J. Zha, and D. Zhao, 2016: Estimating the impact of the changes in land use and cover on the surface wind speed over the East China Plain during the period 1980-2011. Climate Dyn., 46, 847-863, https://doi.org/10.1007/s00382015-2616-z.

,,--- , and Q. Yang, 2018: Changes in terrestrial near-surface wind speed and their possible causes: An overview. Climate Dyn., 51, 2039-2078, https://doi.org/10.1007/s00382-017-3997-y.

$\mathrm{Xu}$, M., C.-P. Chang, C. Fu, Y. Qi, A. Robock, D. Robinson, and H. Zhang, 2006: Steady decline of East Asian monsoon winds, 1969-2000: Evidence from direct ground measurements of wind speed. J. Geophys. Res., 111, D24111, https://doi.org/ 10.1029/2006JD007337.

Yang, X., and Coauthors, 2012: The decreasing wind speed in southwestern China during 1969-2009, and possible causes. Quat. Int., 263, 71-84, https://doi.org/10.1016/j.quaint.2012.02.020.

Young, I. R., and A. Ribal, 2019: Multiplatform evaluation of global trends in wind speed and wave height. Science, 364, 548552, https://doi.org/10.1126/science.aav9527.
Yu, R., J. Li, and H. Chen, 2009: Diurnal variation of surface wind over central eastern China. Climate Dyn., 33, 1089-1097, https://doi.org/10.1007/s00382-008-0478-3.

Yu, Y., J. Li, J. Xie, and C. Liu, 2016: Climatic characteristics of thunderstorm days and the influence of atmospheric environment in Northwestern China. Nat. Hazards, 80, 823-838, https://doi.org/10.1007/s11069-015-1999-9.

Zeng, Z., and Coauthors, 2019: A reversal in global terrestrial stilling and its implications for wind energy production. Nat. Climate Change, 9, 979-985, https://doi.org/10.1038/s41558019-0622-6.

Zhang, G., C. Azorin-Molina, P. Shi, D. Lin, J. A. Guijarro, F. Kong, and D. Chen, 2019: Impact of near-surface wind speed variability on wind erosion in the eastern agro-pastoral transitional zone of Northern China, 1982-2016. Agric. For. Meteor., 271, 102-115, https://doi.org/10.1016/j.agrformet.2019.02.039.

Zhang, J., C. Zhang, C. Chang, R. Wang, and G. Liu, 2017: Comparison of wind erosion based on measurements and SWEEP simulation: A case study in Kangbao County, Hebei Province, China. Soil Tillage Res., 165, 169-180, https:// doi.org/10.1016/j.still.2016.08.006.

Zhang, Q., X. Ni, and F. Zhang, 2017: Decreasing trend in severe weather occurrence over China during the past 50 years. Sci. Rep., 7, 42310, https://doi.org/10.1038/srep42310.

Zhang, R., Q. Li, and R. Zhang, 2014: Meteorological conditions for the persistent severe fog and haze event over eastern China in January 2013. Sci. China Earth Sci., 57, 26-35, https:// doi.org/10.1007/s11430-013-4774-3. 